University of Wollongong

Research Online

Faculty of Science, Medicine and Health -

Papers: Part B

Faculty of Science, Medicine and Health

$1-1-2019$

Subduction accretion and orocline development in modern and ancient settings: Implications of Japanese examples for development of the New England Orogen of eastern Australia

Chris L. Fergusson

University of Wollongong, cferguss@uow.edu.au

Follow this and additional works at: https://ro.uow.edu.au/smhpapers1

Publication Details Citation

Fergusson, C. L. (2019). Subduction accretion and orocline development in modern and ancient settings: Implications of Japanese examples for development of the New England Orogen of eastern Australia. Faculty of Science, Medicine and Health - Papers: Part B. Retrieved from https://ro.uow.edu.au/ smhpapers1/795

Research Online is the open access institutional repository for the University of Wollongong. For further information contact the UOW Library: research-pubs@uow.edu.au 


\title{
Subduction accretion and orocline development in modern and ancient settings: Implications of Japanese examples for development of the New England Orogen of eastern Australia
}

\author{
Abstract \\ The southern New England Orogen of eastern Australia is a component of the Palaeozoic palaeo-Pacific \\ active margin of Gondwana (the Terra Australis Orogen) and is characterised by subduction complex \\ terranes marked by orogenic curvature that are collectively termed the New England oroclines and include \\ the Z-shaped coupled western Texas and eastern Coffs Harbour oroclines. This study addresses the \\ problem of why these two oroclines were initiated and has involved examination of the accretionary \\ development of the New England subduction complex based on comparisons with onland accretionary \\ belts of southwest Japan and the active subduction zone associated with southwest Japan (the Nankai \\ Trough). The main outcome is recognition that the Texas Orocline was nucleated during subduction of a \\ seamount chain resulting in orogenic curvature of the Carboniferous subduction complex. Subduction of \\ the seamount chain is shown by abundant limestone associated with ocean island basalts amongst the \\ accreted turbidites in the core of the Texas Orocline. Further enhancement of the initial curvature of the \\ Texas and adjacent Coffs Harbour oroclines continued in the Early Permian in a backarc setting \\ influenced by rollback as argued by previous authors, although the role of this rollback process in orocline \\ development has been overstated as no oceanic backarc basin developed during this process. The \\ accretionary history of the subduction complex of the southern New England Orogen is resolved into two \\ distinct phases: an earlier phase in the Devonian with accretion of an island arc - backarc basin resulting \\ in larger thrust slices analogous to those in the Honshu - Izu-Bonin-Marianas collision zone, and the \\ Carboniferous phase involving accretion of dominantly trench-wedge deposits during which the Texas \\ and Coffs Harbour oroclines were nucleated.

\section{Publication Details} \\ Fergusson, C. L. (2019). Subduction accretion and orocline development in modern and ancient settings: \\ Implications of Japanese examples for development of the New England Orogen of eastern Australia. \\ Journal of Geodynamics, 129 117-130.
}




\title{
Subduction accretion and orocline development in modern and ancient settings: implications of Japanese examples for development of the New England Orogen of eastern Australia
}

\author{
C. L. Fergusson
}

School of Earth and Environmental Sciences, University of Wollongong, NSW 2522, Australia

E-mail: cferguss@uow.edu.au

Fergusson C. L. 2019. Subduction accretion and orocline development in modern and ancient settings: Implications of Japanese examples for development of the New England Orogen of eastern Australia. Journal of Geodynamics 129, 117-130. (available online 5 December 2017), https://doi.org/10.1016/j.jog.2017.11.008.

\begin{abstract}
The southern New England Orogen of eastern Australia is a component of the Palaeozoic palaeo-Pacific active margin of Gondwana (the Terra Australis Orogen) and is characterised by subduction complex terranes marked by orogenic curvature that are collectively termed the New England oroclines and include the Z-shaped coupled western Texas and eastern Coffs Harbour oroclines. This study addresses the problem of why these two oroclines were initiated and has involved examination of the accretionary development of the New England subduction complex based on comparisons with onland accretionary belts of southwest Japan and the active subduction zone associated with southwest Japan (the Nankai Trough). The main outcome is recognition that the Texas Orocline was nucleated during subduction of a seamount chain resulting in orogenic curvature of the Carboniferous subduction complex. Subduction of the seamount chain is shown by abundant limestone associated with ocean island basalts amongst the accreted turbidites in the core of the Texas Orocline. Further enhancement of the initial curvature of the Texas and adjacent Coffs Harbour oroclines continued in the Early Permian in a backarc setting influenced by rollback as argued by previous authors, although the role of this rollback process in orocline development has been overstated as no oceanic backarc basin developed during this process. The accretionary history of the subduction complex of the southern New England Orogen is resolved into two distinct phases: an earlier phase in the Devonian with accretion of an island arc - backarc basin resulting in larger thrust slices analogous to those in the Honshu - Izu-Bonin-Marianas collision zone, and the Carboniferous phase involving accretion of dominantly trench-wedge deposits during which the Texas and Coffs Harbour oroclines were nucleated.
\end{abstract}

Key words: ocean plate stratigraphy; orocline; plate tectonics; seamount chain; subduction accretion

\section{Introduction}

The Terra Australis Orogen has developed along the Palaeozoic to Mesozoic palaeo-Pacific facing active margin of Gondwana (Figs. 1, 2) (Cawood, 2005) where the roles of subduction accretion have been particularly recognised in Late Palaeozoic development of eastern Australia and Chile (Bahlburg et al., 2009; Donchak et al., 2013). The New England Orogen in eastern Australia (Fig. 3) has a well-developed Late Devonian to Carboniferous east-facing 
convergent margin assemblage with an eastern subduction complex (Leitch, 1974, 1975; Murray et al., 1987; Aitchison et al., 1992). The southern New England Orogen has several examples of orogenic curvature (oroclines, Carey, 1955) developed in subduction complex units (Fig. 3) and attributed to bending and/or vertical axis block rotations (Cawood, 2011a, b; Fielding et al., 2016; Rosenbaum, 2012; Shaanan et al., 2014; White et al., 2016). In the adjacent Lachlan Orogen (Fig. 3a), a major double orocline has been recognised in lower Palaeozoic accretionary rocks (Cayley, 2012) and modelled by computer simulations with accretion of a buoyant microcontinent causing the orogenic curvature (Moresi et al., 2014). Elsewhere, oroclines are well displayed in collision belts such as the Indian-Asian collision zone where syntaxes occur at the two corners of the Indian indentor (Fig. 1) (Bajolet et al., 2013). Smaller-scale flexures are found in active convergent margins including southwest Japan (Fig. 4) where flexed structural trends on the Muroto Peninsula are interpreted to have formed from impingement of the Cenozoic Shimanto belt by subduction of the Shikoku backarc basin extinct sea-floor spreading ridge (Hibbard and Karig, 1990; Hibbard et al, 1992; Kimura et al., 2014). The Kanto Syntaxis (Fig. 4), an orocline formed by the curved Mesozoic-Cenozoic accretionary belts of southwest Japan, is also developed in the Tokyo region of Japan where the Izu-Bonin-Marianas arc is presently colliding with the Honshu arc (Niitsuma, 1989; Takahashi, 1994; Takahashi and Saito, 1997; Hoshi and Sano, 2013). Curved belts not directly caused by collision are also commonly associated with island arcs in general and deformed belts in the western Mediterranean Sea where they are related to rollback and sea-floor spreading in backarc basins (Rosenbaum, 2014).

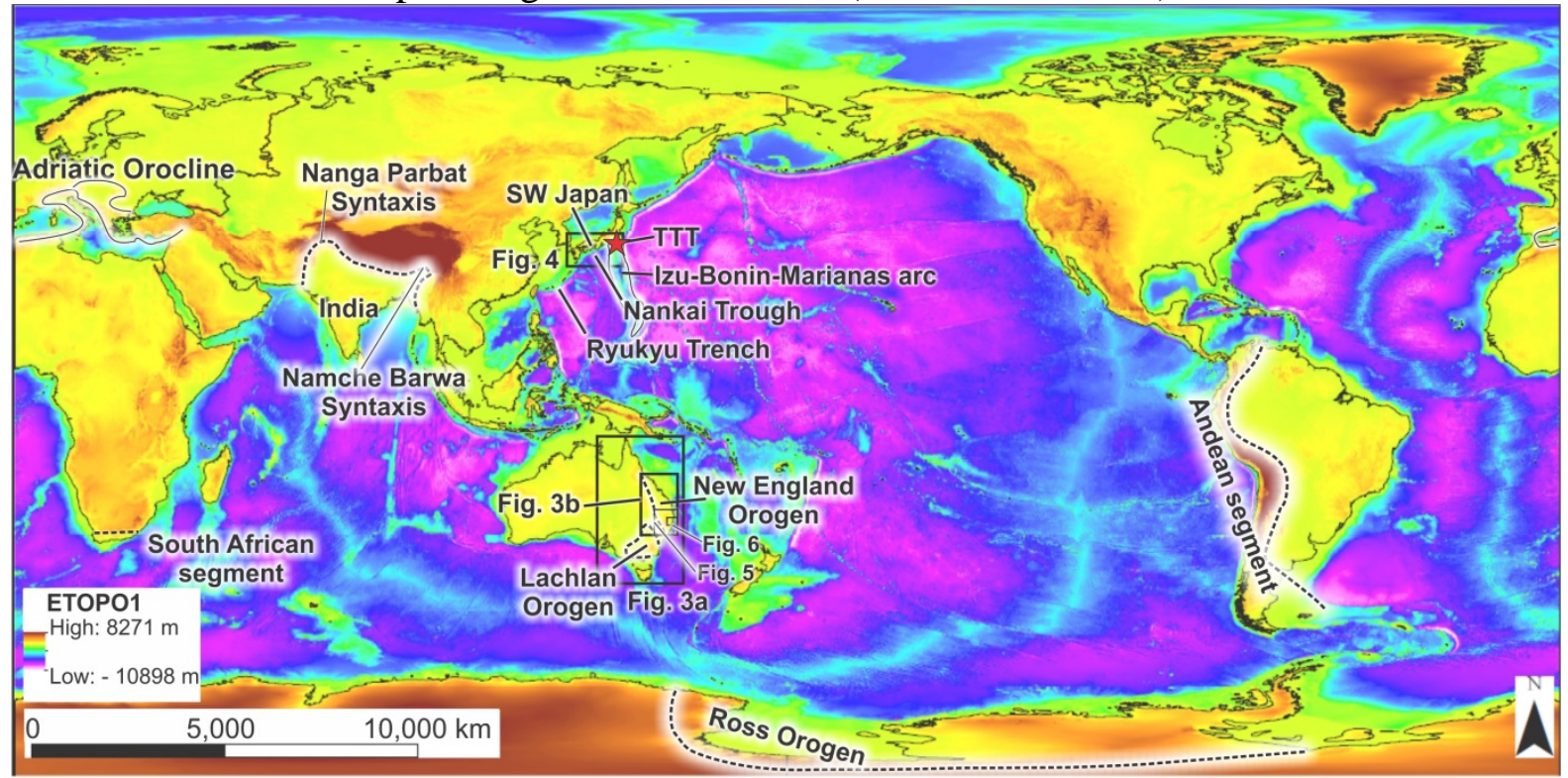

Fig. 1. Global map with ETOPO1 topographic data as a base from Amante and Eakins (2009) showing major features referred to in the text and also showing components of the Terra Australis Orogen (Andean segment, Lachlan Orogen, New England Orogen, Ross Orogen, South African segment, Cawood, 2005). Red star marks location of the trench-trench-trench (TTT) triple junction (see text). Locations of Figs. 3 to 6 are shown. 


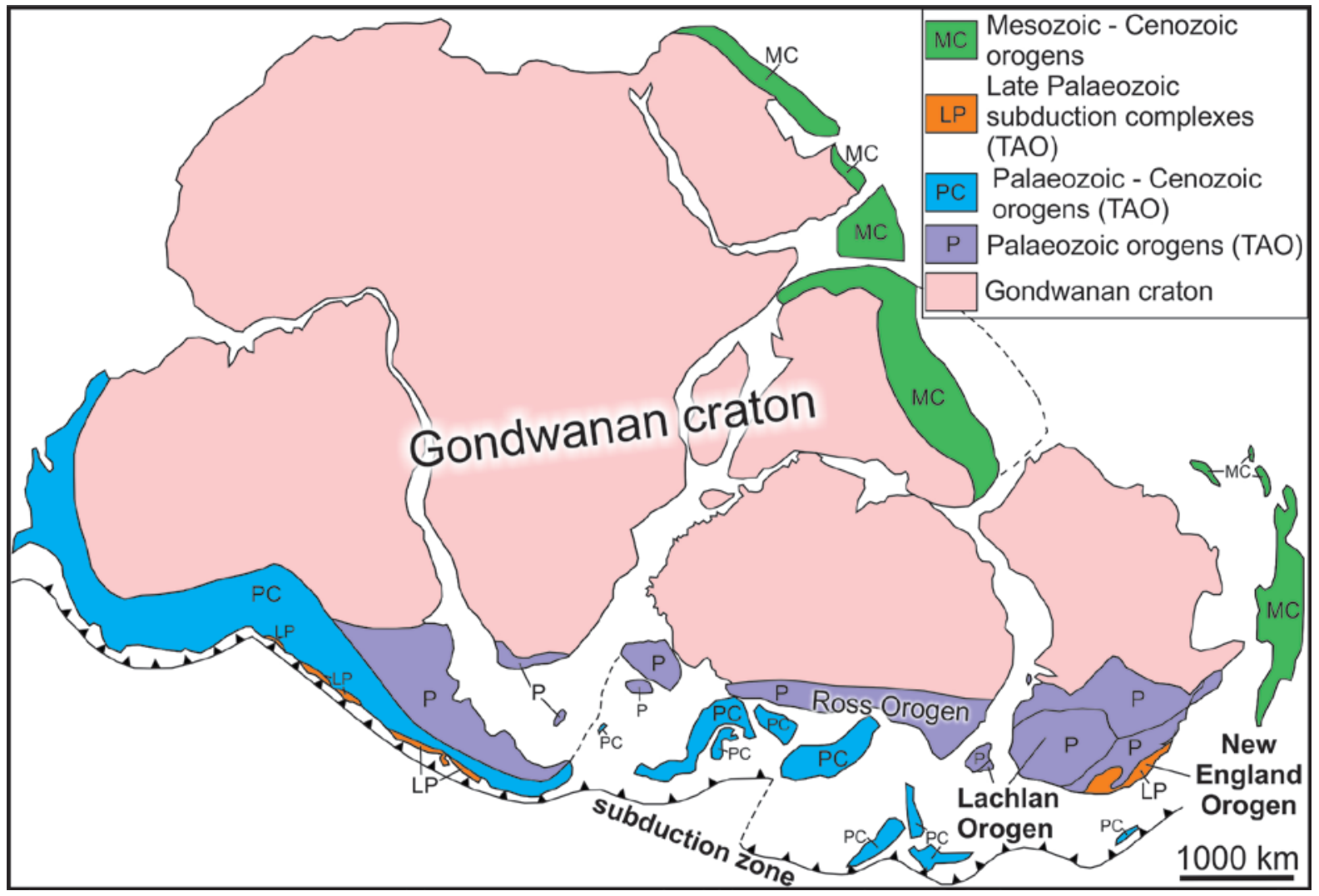

Fig. 2. Gondwanan reconstruction of $\sim 150 \mathrm{Ma}$ (after de Wit et al., 1988) showing the Terra Australis Orogen (TAO). 


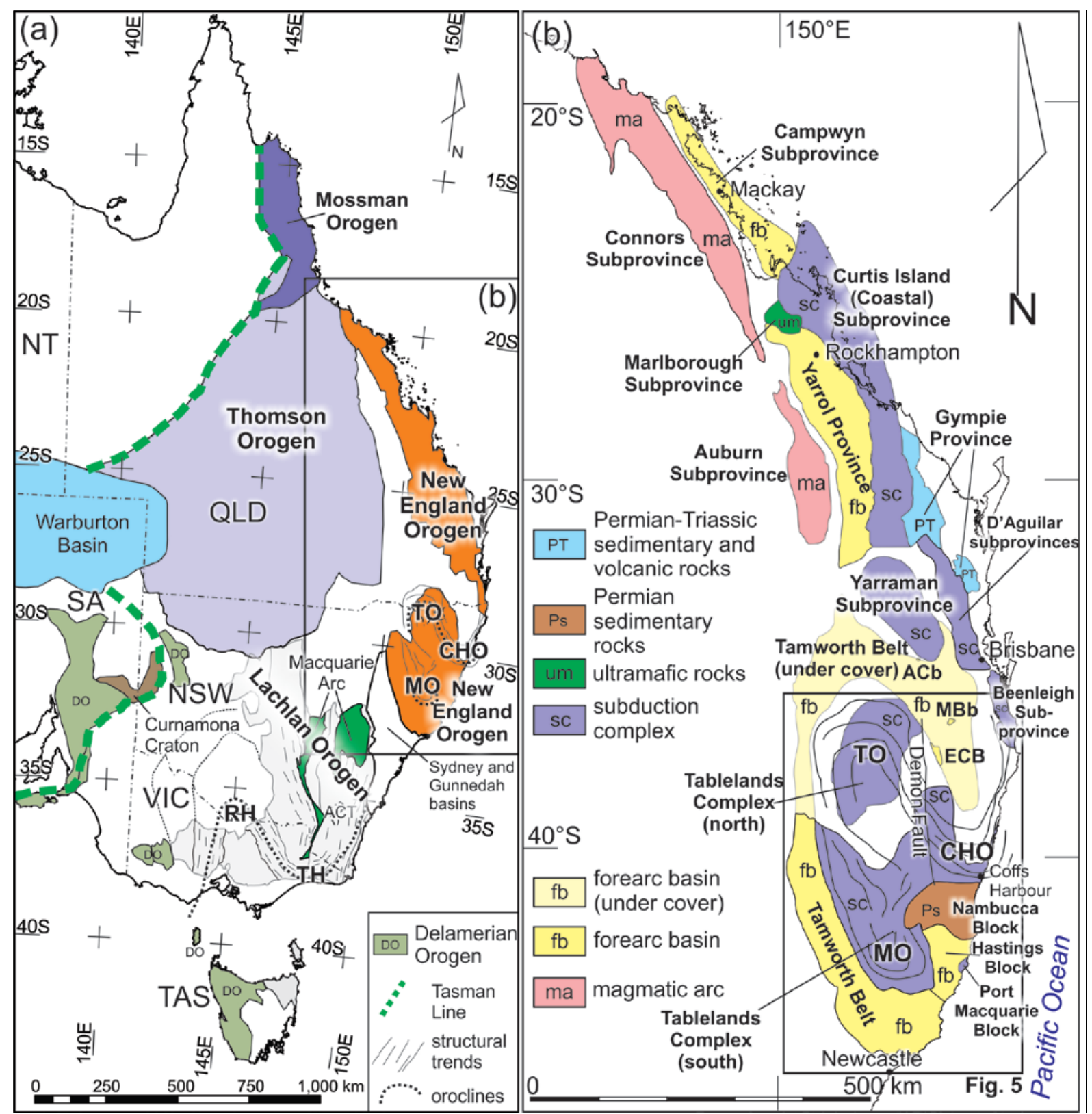

Fig. 3. (a) Map of the Tasmanides of eastern Australia showing the main orogenic belts with oroclines shown for the Lachlan and New England orogens. Terminology of oroclines after Musgrave (2015) and Shaanan et al. (2015a). See Fig. 1 for location. Location of (b) shown. Abbreviations: ACT - Australian Capital Territory, RH - Riverina Hinge of the Lachlan Orocline, TH - Tambo Hinge of the Lachlan Orocline, CHO - Coffs Harbour Orocline, MO - Manning Orocline, TO - Texas Orocline. (b) Simplified map of the New England Orogen with Late Devonian to Carboniferous tectonic elements. Abbreviations as for (a). See Fig. 1 and (a) for location. Location of Fig. 5 is shown. 


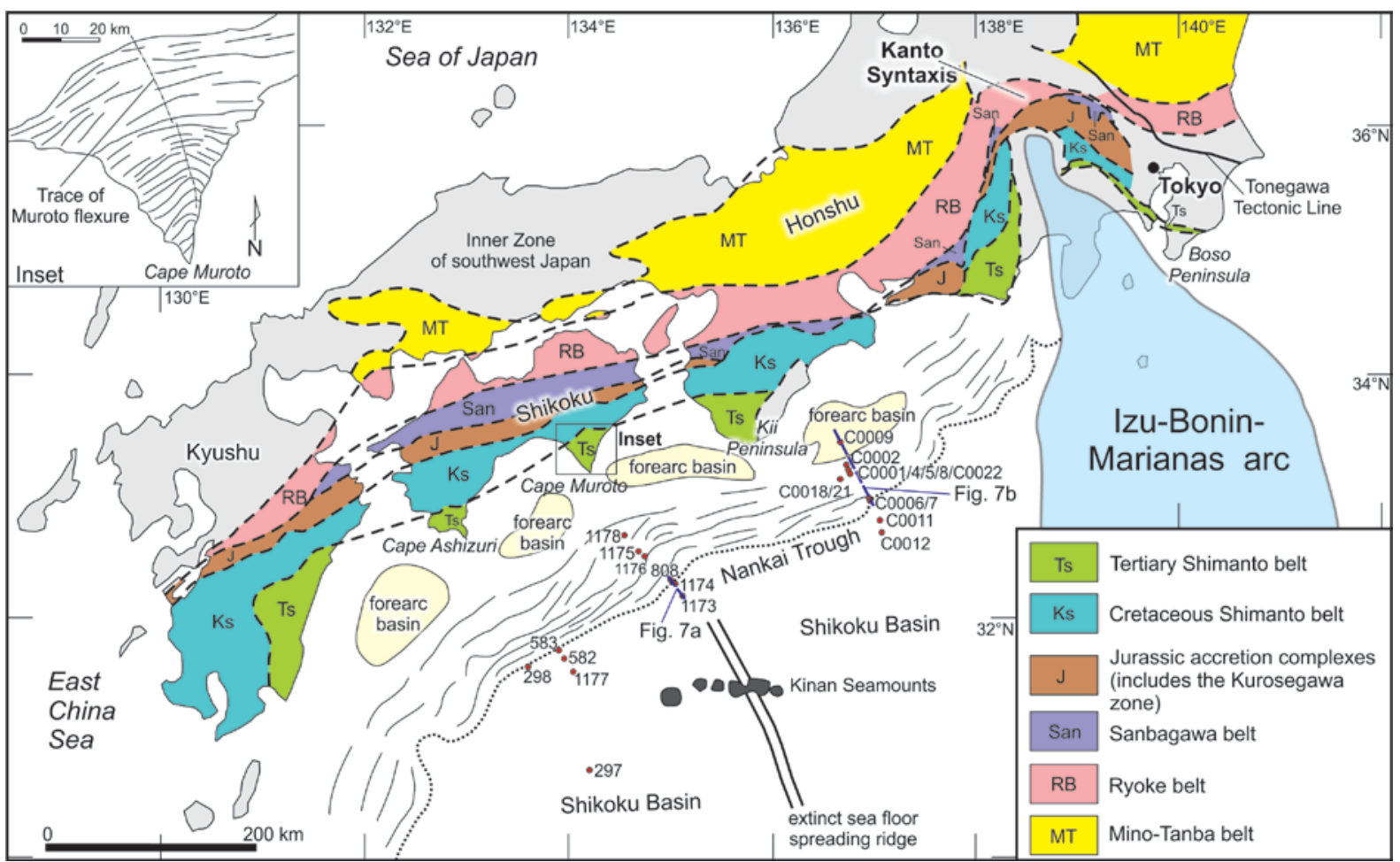

Fig. 4. Map of southwest Japan showing the contacts between the main accretionary units (colour coded) and their inferred subsurface extension where covered by younger units. Gray areas are undifferentiated and mainly covered by Cenozoic volcanic rocks and sediments. Parts of most of these accretionary units form the curved trends of the Kanto Syntaxis around the indenting Izu-Bonin-Marianas arc. Also shown is the Nankai Trough and associated submarine topography including trend lines on the inner slope of the Nankai Trough based on submarine ridges that reflect uplift on blind thrust faults. The forearc basin is restricted to several basins separated by submarine ridges extending from the main peninsulas including Cape Ashizuri, Cape Muroto and the Kii Peninsula. Ocean drilling sites shown (numbered red dots) along with seismic lines given in Fig. 7. Inset shows the flexed structural trends across Cape Muroto (after Hibbard et al., 1992). The flexure in Cape Muroto was caused by subduction of the spreading ridge in the Shikoku Basin (Hibbard and Karig, 1990). See Fig. 1 for location.

This paper examines the relationship between subduction accretion processes and the initiation of oroclines based on the Texas and Coffs Harbour oroclines of the southern New England Orogen (Fig. 3) (Li et al., 2012; Mochales et al., 2014; Shaanan et al., 2014) using analogies from the more thoroughly documented accretionary units of southwest Japan and modern subduction accretion processes in the Nankai Trough (Fig. 4) (Isozaki et al., 1990, 2010; Underwood and Moore, 2012). The origin of oroclines is problematic in the Tasmanides with some authors arguing for orocline formation during accretionary development as for the Riverina and Tambo hinges in the Lachlan Orogen (Moresi et al., 2014) whereas orocline formation in the southern New England Orogen has been more difficult to resolve but was at least partly driven by rollback in an Early Permian backarc setting (Rosenbaum, 2012; Rosenbaum et al., 2012). The subduction complex units of the southern New England Orogen and their map pattern in the Texas and Coffs Harbour oroclines, and to a lesser extent in the Manning orocline, are firstly reviewed with additional information given in Supplementary data. This is followed by an outline of subduction accretion in the Nankai Trough, the accretionary units of southwest Japan and related examples of orogenic curvature. These examples provide a clearer picture of the tectonic 
processes in accretionary orogens and accompanying oroclinal folding than what can be deduced from the complicated oroclinal patterns evident in the southern New England Orogen. Finally, these are discussed with the aim of showing the role of accretionary processes with impingement of a seamount chain associated with initiation of the Texas and Coffs Harbour oroclines of the southern New England Orogen.

\section{Southern New England Orogen}

In this section, the tectonic setting of the problematic oroclines of the southern New England Orogen is outlined. These oroclines have been widely discussed in the literature (e.g. Cawood et al., 2011a, b; Rosenbaum, 2012; Rosenbaum et al., 2012; White et al., 2016) but it is still unclear why and how they were initiated.

The late Palaeozoic active margin of the Terra Australis Orogen is most clearly evident in the New England Orogen of eastern Australia (Fig. 3). This orogenic belt has a long-lived history with Cambrian ophiolitic rocks and island arc rocks developed astride the Peel Fault (Fig. 5) in northeastern New South Wales (Glen, 2013). Most of the geology is dominated by Devonian to Triassic subduction-related assemblages with a magmatic arc, forearc basin and subduction complex well developed in the Carboniferous (Fig. 3b) and overprinted by a widespread Late Permian to Early Triassic magmatic assemblage related to eastward retreat of the subducting plate (Murray et al., 1987; Donchak et al., 2013). Problematic aspects of the southern New England Orogen are several oroclines that are most notably developed in the subduction complex rocks but also affect the forearc basin (Fig. 5) (Hoy et al., 2014). The position of the Hastings Block is puzzling; it is an offset and rotated portion of the forearc basin (Yan et al., 2016), that was possibly displaced during formation of the Manning Orocline (Fielding et al., 2016; White et al., 2016). Much emphasis has been placed on the development of these features in the recent literature with tectonic interpretations (Cawood et al., 2011a, b; Shaanan et al., 2015a, b), descriptions of structural trends (Rosenbaum, 2012; Li et al, 2012; Li and Rosenbaum, 2014; White et al., 2016), considerations of timing (Li et al., 2014; Shaanan et al., 2015b), and documentation of palaeomagnetic data (Aubourg et al., 2004; Mochales et al., 2014; Shaanan et al., 2015a). Some authors have queried the existence of these oroclines (Buckman et al., 2015) and others have challenged the southern Manning Orocline (Offler et al., 2015). Magnetic and gravity images of the southern New England Orogen clearly outline the Texas and Coffs Harbour oroclines (Rosenbaum, 2012; Musgrave, 2015).

In the southern New England Orogen, the Peel Fault separates the accretionary Tablelands Complex to the east from the predominantly forearc basin rocks of the Tamworth Belt to the west and south (Fig. 5). The Tamworth Belt contains two main successions; an older assemblage of inferred Cambrian to mid-Upper Devonian rocks consists of maficintermediate volcanic and volcaniclastic rocks, and shallow marine limestone, which are interpreted to have formed in an island arc to backarc setting (Offler and Murray, 2011). These are unconformably overlain by mid-Upper Devonian to Upper Carboniferous, mainly clastic rocks with a dominant volcanic provenance and deposited in deep-marine to fluvial environments that were part of a forearc basin (Leitch, 1975; Murray et al., 1987; Flood and Aitchison, 1992). 


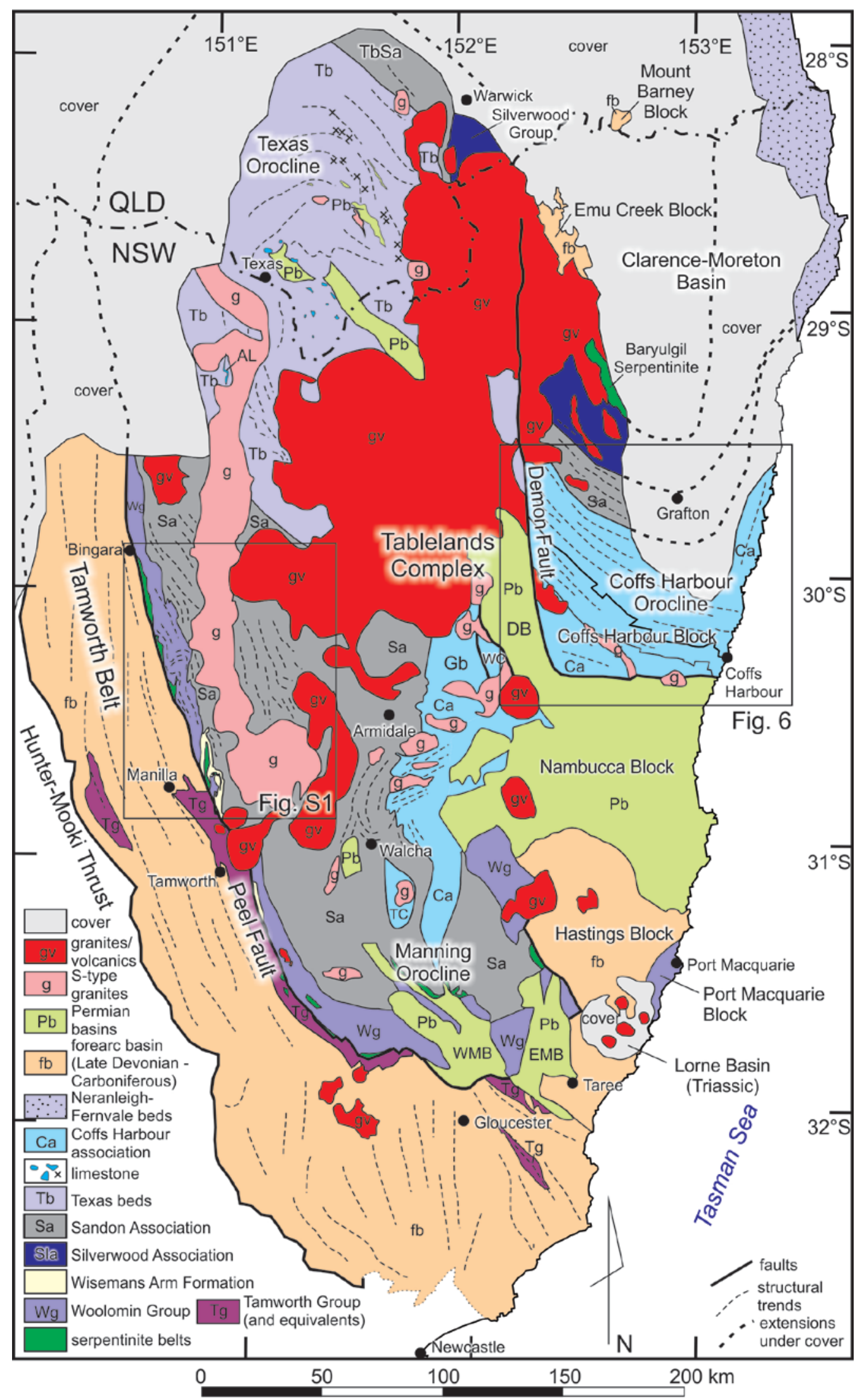

Fig. 5. Map of the southern New England Orogen with the main accretionary units and structural trends defining the main oroclines. Abbreviations: AL - Ashford Limestone, DB Dyamberin Block, EMB - eastern Manning Basin, Gb - Girrakool beds, TbSa - Sandon association recognised as a subunit of the Texas beds (Donchak et al., 2007), TC - Tia 
Complex, WC - Wongibinda Complex, WMB - western Manning Basin. Cenozoic sediments and volcanic rocks are omitted. Fig. S1 included in Supplementary data. Location of Fig. 6 is shown. See Figs. 1 and 3b for location.

\subsection{Accretionary units of the southern Tablelands Complex}

The accretionary units of the southern Tablelands Complex are given (more detail in Supplementary data) and their relationship to the Manning Orocline outlined. These units are important to showing the accretionary development of the southern New England Orogen and contrast with the character of units in the core of the Texas Orocline farther north.

As well as forming the contact between the subduction complex rocks to the east and the Tamworth Group to the west, the Peel Fault is associated with abundant serpentinite (Leitch, 1974). The serpentinites are mostly east of the Peel Fault (Fig. 5) and occur in an ophiolitic assemblage with gabbro, dolerite, basalt, and early Cambrian plagiogranites (Aitchison et al., 1994; Aitchison and Ireland, 1995). East of the Peel Fault, are a variety of units that include: the Woolomin Group, of probable Late Silurian to Middle Devonian age, the Wisemans Arm Formation of uncertain age, possibly Devonian, the Cara Formation of Late Silurian to Middle Devonian age, the Sandon and Coffs Harbour associations of Carboniferous age, and Lower Permian sedimentary units (Aitchison et al., 1988, 1992; Brown, 2001, 2003, 2009; Korsch, 1977; Vickery et al., 2010).

Overall, in the southern Tablelands Complex, the arrangement of accretionary units appears complex and structural trends are highly variable in the core of the Manning Orocline (Fig. 5). Nevertheless, the overall pattern of units, apart from the poorly controlled Wisemans Arm Formation, as determined from the available age control do broadly young eastwards away from the Peel Fault, consistent with eastward accretionary growth of the subduction complex. The width of Sandon association units increases southwards (Fig. 5). Partly this reflects refolding with development of second generation, steeply plunging, map-scale sinistrally verging folds adjacent to the Peel Fault (Corbett, 1976; Cawood et al., 2011a, b), but also indicates an increased width of accreted Lower Carboniferous deposits southwards along the New England Orogen. The Woolomin Group forms a distinctive marker mappable east of the Peel Fault (Korsch, 1977) and continues southeastwards around the Manning Orocline and then is traced northwards along the western side of the Hastings Block (Fig. 5). In much of the core of the Manning Orocline structural trends reflect widespread multiple deformations of mid Permian age (Dirks et al., 1992), and are considered to overprint the orocline (Phillips et al., 2016).

In summary, the age of accretionary units of the southern New England Orogen are progressively younger eastwards consistent with growth of the east-facing mid to late Palaeozoic subduction complex. Additionally, the prominent cherts of the Woolomin Group and equivalents outline the hinge and limbs of the Manning Orocline.

\subsection{Accretionary units of the northern Tablelands Complex}

In this section, the accretionary units of the northern Tablelands Complex are outlined (more detail in Supplementary data) and the structure of the Texas and Coffs Harbour oroclines (Figs. 3b, 5) reviewed. The northern Tablelands Complex is divided from the southern Tablelands Complex by obscuring Cenozoic basaltic lavas and Lower Permian rocks of the 
Nambucca and Dyamberin blocks (Fig. 5). Units of the Texas and Coffs Harbour oroclines are only partly comparable to those of the southern Tablelands Complex.

The Coffs Harbour Orocline is contained within the Coffs Harbour Block that is bounded to the west with the Lower Permian Dyamberin Block by the Demon Fault (Fig. 5)

(Babaahmadi and Rosenbaum, 2013; Shaanan et al., 2015b). To the south it is faulted against Lower Permian rocks of the Nambucca Block (Leitch and Asthana, 1985). Subdivision of accretionary units in the Coffs Harbour Block from north to south includes (Figs. 5, 6): the Willowie Creek beds (part of the Silverwood association of Korsch, 1977), the Gundahl Complex, the Cunglebung Creek beds, and the Coffs Harbour sequence, which includes the Coramba beds, the Brooklana beds, and the Moombil beds (Korsch, 1978a, 1981a, b; Fergusson, 1982, 1984). In the northern part of the Coffs Harbour Block the Willowie Creek beds are in contact to the east with the northerly trending Baryulgil Serpentinite Belt (Fig. 5) (Fergusson, 1984). 


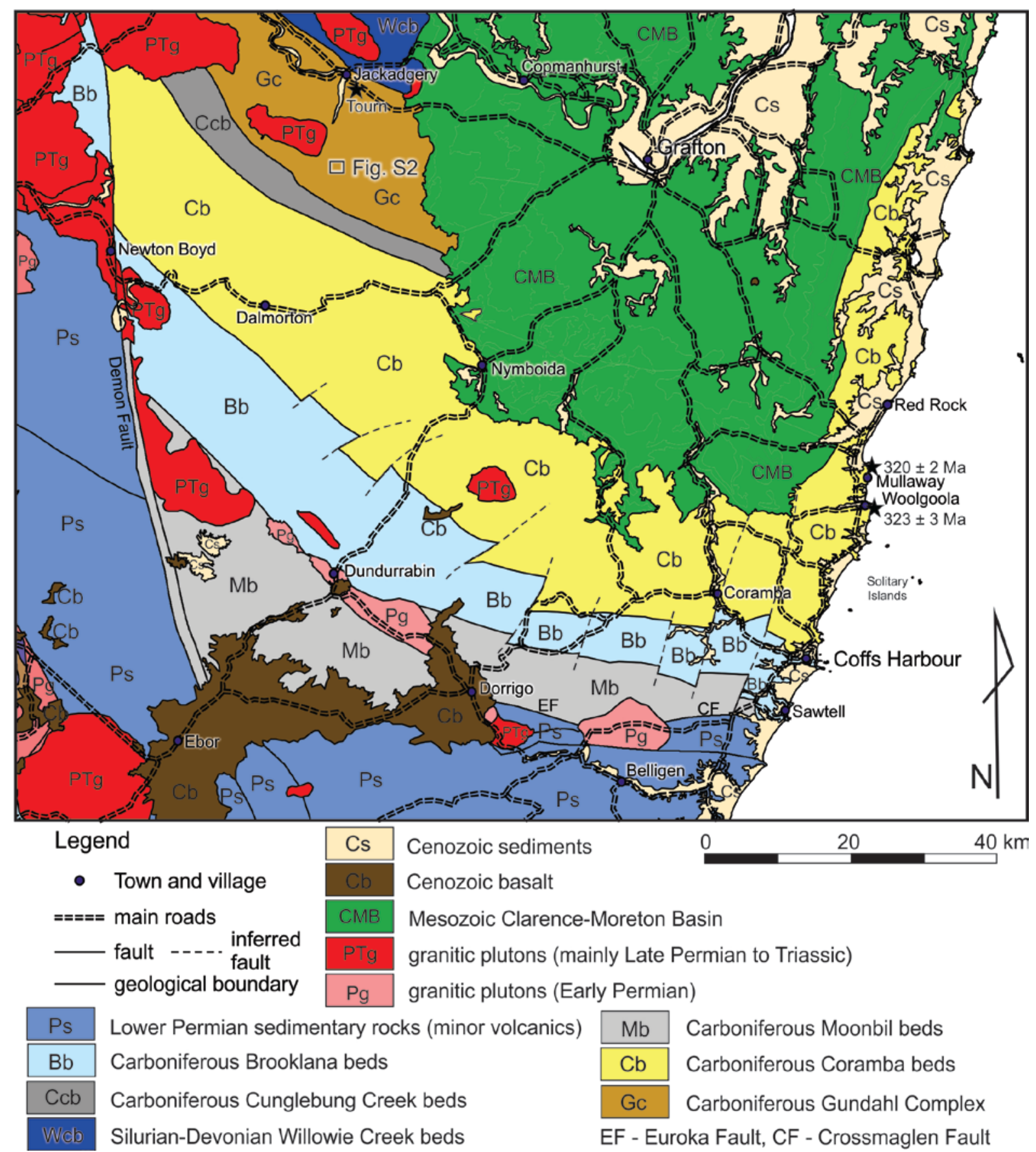

Fig. 6. Geological map of the southern Coffs Harbour showing Palaeozoic units folded around the Coffs Harbour Orocline (modified from Raymond et al., 2012). Stars - fossil locality of Aitchison (1988) and zircon sample sites of Korsch et al. (2009). Inferred faults based on interpreted offsets of petrofacies units in the Coramba beds (Korsch, 1978b). For location see Figs. 1 and 5.

The Coffs Harbour Orocline was originally defined by Korsch (1981b) with the Coffs Harbour sequence forming a map-scale, steeply north-plunging curved structure in the southern Coffs Harbour Block. The western limb is gently curved with northwest to east-west trends and an angular hinge developed east of the coastline as shown by curved structural trends in the Solitary Islands northeast of Coffs Harbour (Fig. 6) (Korsch, 1993). NNE trends on the eastern limb of the curved structure occur in the coastal exposures east of the 
Clarence-Moreton Basin north of Mullaway (Fig. 6) (Korsch, 1981b; Rosenbaum et al., 2015). The map-scale curved structure was interpreted as a second generation structure reflecting folding of the earlier generation folds and axial planar cleavage (Korsch, 1981b). Cleavage and bedding orientations around the Coffs Harbour orocline (Korsch, 1981b; Fergusson, 1982) are consistent with magnetic and gravity trends and the orientation of magnetic fabric data (Aubourg et al., 2004; Musgrave, 2015; Rosenbaum et al., 2015). The core of the structure is shown in geophysical data outlining the curved structure farther north beneath the Upper Triassic to Lower Cretaceous Clarence-Moreton Basin (Musgrave, 2015).

The main units of the Texas Orocline include the Silverwood Group in the east (part of the Silverwood association of Korsch, 1977) and the Texas beds that dominates the core and eastern limb of the orocline (Fig. 5). The curved structural trend of the Texas Orocline is also defined by orientation data from bedding and cleavage that indicate a second generation steeply plunging curved structure (Fig. 5), which overprints earlier accretionary structures including tight folds, axial planar cleavage and abundant exposures of disrupted rocks (Fergusson and Flood, 1985; Lennox and Flood, 1997; Li et al., 2012; Campbell et al., 2015). The structural trend defining the Texas Orocline is also shown from radiometric and magnetic data, and also at a broader scale by curved gravity trends (Donchak et al., 2007; Mochales et al., 2014; Musgrave, 2015).

Correlations of accretionary units between the Coffs Harbour and Texas oroclines are obscured by Permian-Triassic granites and volcanics between the two oroclines (Fig. 5) and also affected by $25 \mathrm{~km}$ post-mid Triassic dextral offset along the Demon Fault (Babaahmadi and Rosenbaum, 2013). The subsurface continuation of the Baryulgil Serpentinite to the north is interpreted to link with a curved northern continuation of the Peel Fault (Fig. 5) (BrookeBarnett and Rosenbaum, 2015) and separates the Silverwood Group/Willowie Creek beds from the Carboniferous forearc basin rocks of the Emu Creek and Mt Barney blocks (Murray et al., 1987; Hoy et al., 2014). The most distinctive units of the Texas and Coffs Harbour oroclines are those of the Devonian Silverwood Group, with arc-related mafic-intermediate volcanics and volcaniclastic sedimentary rocks, and the equivalent but less well studied Willowie Creek beds (van Noord, 1999) providing a link between the oroclines. Equivalent rocks (Tamworth Group and/or Gamilaroi terrane) in the Tamworth Belt are mainly west of the Peel Fault (Cawood, 1983). Thus the Silverwood Group/Willowie Creek beds are anomalously located in a broader context, as they lie west of the Baryulgil Serpentinite, rather than east of it as would be expected from bending around the Texas Orocline.

The Gundahl Complex is a distinctive marker in the Coffs Harbour Block and is potentially equivalent to the Sandon association subunit of the Texas beds (Fig. 5, TbSa) (see Supplementary data). This subunit locally contains oolith-bearing greywackes and other rock types typical of the Gundahl Complex and was considered equivalent to it by Fergusson and Flood (1985). The dominant silicic volcanic source of sandstones in the Coffs Harbour sequence is also a characteristic of the bulk of the Texas beds (Fergusson and Flood, 1985; Donchak et al., 2007). Age data are presently insufficient to establish a correlation between the Coffs Harbour sequence and the bulk of the Texas beds but it was inferred by Fergusson and Flood (1982) and Murray et al. (1987). A significant feature of the Texas beds is the abundance of Visean limestones associated with mafic volcanics of ocean island affinity (Donchak et al., 2007; Buchs et al., 2010; see Supplementary data) which are absent from Carboniferous accretionary units of the Coffs Harbour and Manning oroclines. 
In summary, the accretionary units northern Tablelands Complex includes a unit of arc/backarc affinity (the Silverwood association of Korsch, 1977) as well as abundant turbidite-dominated accretionary units that define the structural trends of the Texas and Coffs Harbour oroclines. In contrast to the southern Tablelands Complex the Woolomin Group is missing. The Texas beds in the core of the Texas Orocline are distinguished from other Carboniferous accretionary units of the southern New England Orogen by the abundance of Visean limestone occurrences associated with mafic rocks of ocean island magmatic affinity.

\section{Modern and ancient examples of subduction accretion, collision, and oroclinal bending in Japan}

The late Palaeozoic plate tectonic setting of the New England Orogen and accompanying orocline development is difficult to resolve given the lack of any oceanic plates of this age. It is therefore instructive to compare the New England Orogen with relevant younger settings where the plate tectonic setting is more firmly established. Japan is selected as a younger setting for comparative analysis as it is ideal for the examination of subduction accretion and oroclinal bending because of the well-studied onland accretionary complexes and the detailed offshore analysis of subduction processes in the Nankai Trough (Isozaki et al., 1992, 2010; Underwood and Moore, 2012). Collision of the Izu-Bonin-Marianas arc is also related to the Kanto Syntaxis, which has affected the major Mesozoic to Cenozoic accretionary belts of southwest Japan (Takahashi and Saito, 1997), and at least partially resembles the structure of the Texas Orocline.

\subsection{Setting of the Nankai Trough}

The modern subduction- controlled setting of the Nankai Trough (Fig. 1) is briefly outlined in this section. Although the onland geology of Japan is well studied the tectonic development of the last 15-20 Ma is still much debated including motion of the triple junction between the Honshu and Izu-Bonin-Marianas arcs (e.g. Kimura et al., 2014; Wu et al., 2016).

The Nankai Trough is associated with subduction of the Shikoku Basin under southwest Japan (Fig. 4) (Underwood and Moore, 2012). It has water depths < $5000 \mathrm{~m}$ reflecting the young age of sea floor of the Shikoku Basin (27-14 Ma, Okino et al., 1999) and the thick sediment pile within it (Fig. 7). Its eastern termination is where the northern part of the IzuBonin-Marianas arc is presently colliding with the Honshu arc at a trench-trench-trench triple junction (Fig. 1) between the Eurasian, Philippine Sea and Pacific plates (Kimura et al., 2014). 


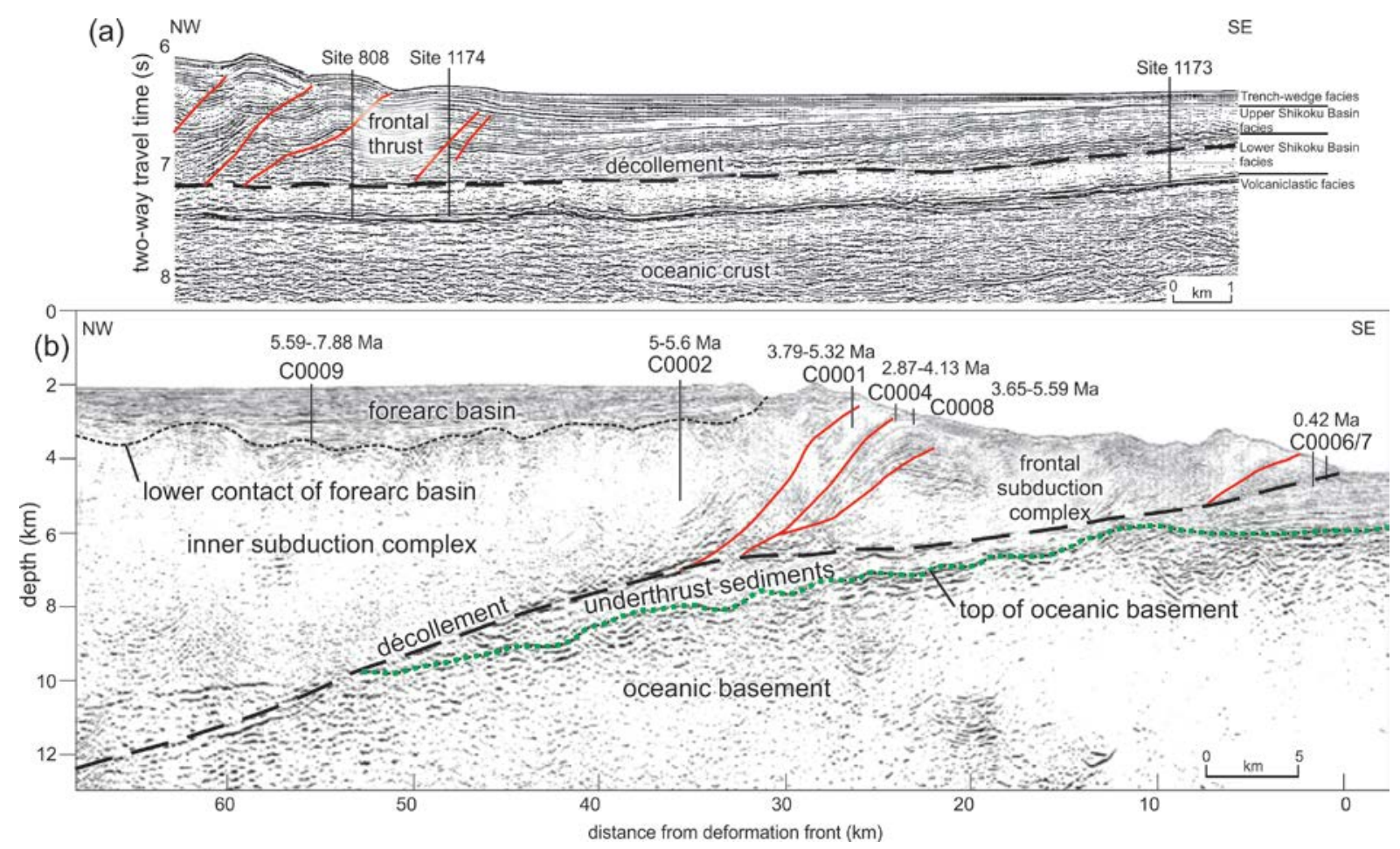

Fig. 7. (a) Seismic profile of the lower trench slope and Nankai Trough along the Muroto transect through Ocean Drilling Program (ODP) sites 808, 1174 and 1173 (see Fig. 4 for location). Modified from Shipboard Scientific Party (2001, fig. F9). Vertical exaggeration is approximately x2. Red lines show thrust faults. (b) Seismic profile of the NanTroSEIZE Kumano transect with drill holes and ages of trench-wedge turbidites (Underwood and Moore, 2012) indicating the timing of accretion to the lower subduction complex (see Fig. 4 for location). Green dotted line is the top of the oceanic basement. Red lines show thrust faults. Modified from Moore et al. (2009). Vertical exaggeration is approximately x2.

Movement of the triple junction has been difficult to determine due to the absence of a suitable reference frame. Two main suggestions have been presented for the motion of this triple junction: (1) it migrated to the northeast along the Nankai Trough and was located at its present position from about 9 Ma onwards concurrent with collision of the Izu-BoninMarianas arc northwards into central Japan (Kimura et al., 2014), and (2) it has been considered more-or-less fixed from about $15 \mathrm{Ma}$ or older as the Izu-Bonin-Marianas arc collided with the Honshu arc forming the Kanto Syntaxis (Takahashi and Saito, 1997; Wu et al., 2016). The first suggestion is consistent with the plate reconstructions of Hall (2002), Sdrolias et al. (2004), and Seton et al. (2012) and with igneous events in Kyushu (Mahony et al., 2011), provenance considerations (Clift et al., 2013; Pickering et al., 2013), and crustal growth of southwest Japan (Kimura et al., 2014). Whereas the more recent reconstructions of Zahirovic et al. (2014) and in particular Wu et al. (2016) are consistent with the second alternative which was also previously argued from constraints within the Izu-Bonin-Marianas arc - Honshu collision zone in central Japan (Niitsuma, 1989; Hibbard and Karig, 1990; Amano, 1991; Taira, 2001; Takahashi and Saito, 1997, 1999) and palaeomagnetic data from the Philippine Sea plate (Yamazaki et al., 2010).

Sea-floor spreading in the Sea of Japan was associated with clockwise rotation of southwest Japan mainly at 17-15 Ma (Otofuji et al., 1991) and was accommodated by subduction along the Nankai Trough (Jolivet et al., 1994). Backarc sea-floor spreading in the Shikoku Basin behind the extensional Izu-Bonin-Marianas arc occurred at 27-14 Ma (Okino et al., 1999). In 
the outer part of southwest Japan at 17-12 Ma anomalous widespread near-trench mafic to silicic igneous activity (Taira, 2001; Kimura et al., 2005) has been attributed to subduction of the spreading ridge in the Shikoku Basin (Kimura et al., 2014). Transform faulting along the western Nankai Trough and northeast Ryukyu Trench (Fig. 1) has been proposed from about 15 to $10 \mathrm{Ma}$ and allowed widespread deposition of quartz-rich turbidites in deeper parts of the Shikoku Basin derived from numerous sources, including the Yangtze River based on detrital zircon ages with a significant population at 1000-600 Ma from ODP Site 1177 but not encountered in younger units of the Nankai Trough (Clift et al., 2013; Pickering et al., 2013).

In summary, the Nankai Trough has had a complicated tectonic history in the last $20 \mathrm{Ma}$ reflecting subduction associated with sea-floor spreading in the Sea of Japan at 17-15 Ma, subduction of the Shikoku Sea spreading ridge and anomalous igneous activity in adjacent southwest Japan. Movement of the trench-trench-trench triple junction between the Honshu and Izu-Bonin-Marianas arcs is not fully resolved but recent reconstructions support it being fixed at the time of initial indentation of the Izu-Bonin-Marianas arc into the Honshu arc at 15 Ma or older (Zahirovic et al., 2014; Wu et al., 2016) consistent with earlier interpretations of the Izu-Bonin-Marianas arc - Honshu collision zone in central Japan (Niitsuma, 1989; Amano, 1991).

\subsection{Nankai Trough accretionary prism and Subduction complex inputs}

In this section, the Nankai Trough accretionary prism and the modern subduction inputs from the Shikoku Basin and Nankai Trough are briefly reviewed (Figs. 7, 8). These provide modern analogues for both the development of accretionary belts in southwest Japan and the southern New England Orogen.

The growth of the Nankai Trough accretionary prism by subduction accretion is well established from the geometry of the fold-thrust system (Fig. 7) (Gulick et al., 2004; Park et al., 2003; Moore et al., 1990, 2007, 2011). In the lower trench-slope from the Muroto transect (Fig. 7a) and the Nankai Trough Seismogenic Zone Experiment (NanTroSEIZE) Kumano Transect (Fig. 7b), seismic profiles show development of classic foreland fold-thrust structures with ramp anticlines and farther north out-of-sequence thrusts (Moore et al., 2007, 2011). Deep-sea drilling along these two transects has shown that the inner-most accreted trench-wedge turbidites were initially incorporated into the toe of the subduction complex at 5-7 Ma and indicates that the accretionary prism is late Neogene to Quaternary (Fig. 7b, 8) (Moore et al., 2001; Underwood and Moore, 2012). 


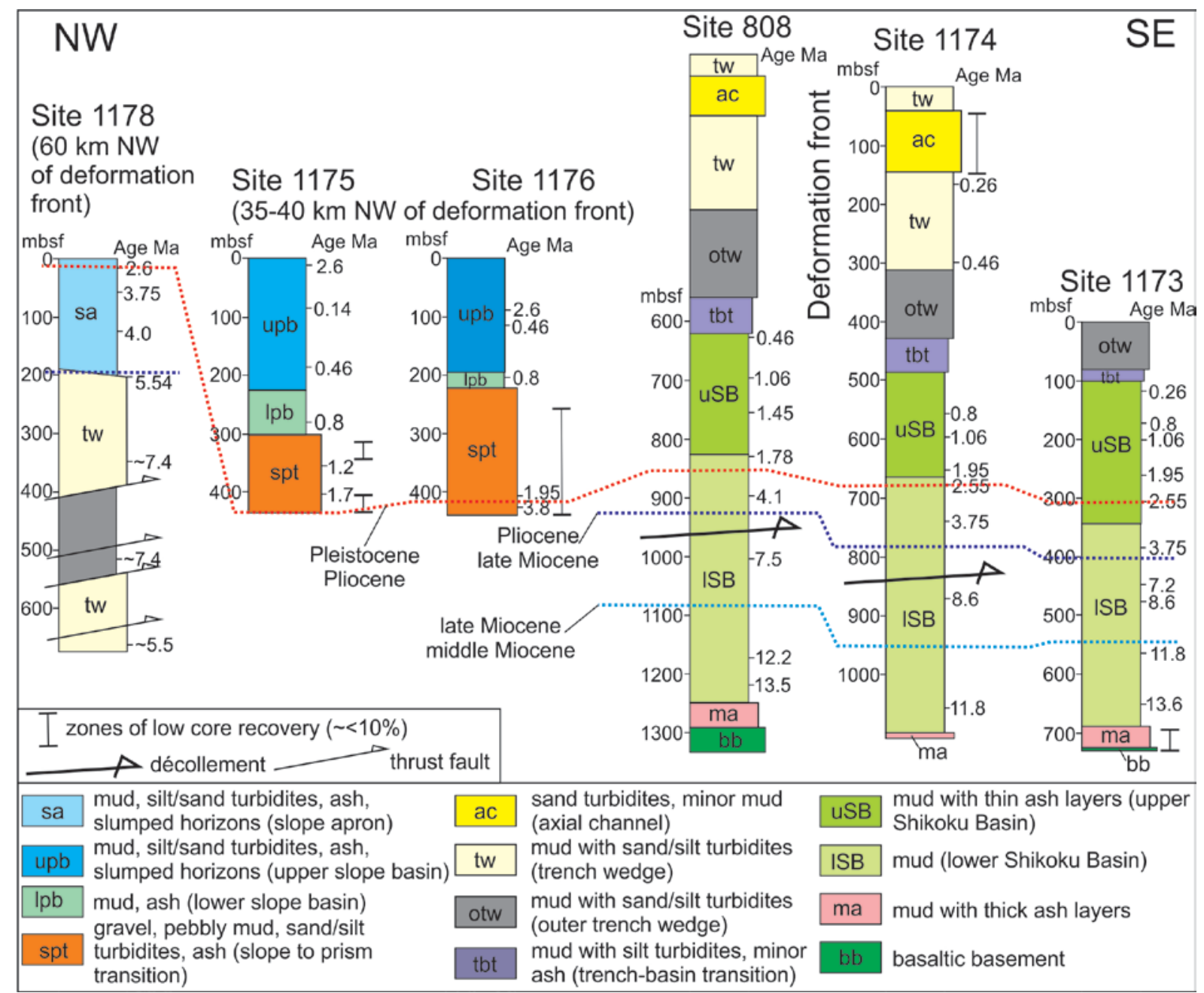

Fig. 8. Summary stratigraphic columns and interpretations of ODP sites along the Muroto transect (see Fig. 4 for location). Modified from Shipboard Scientific Party (2001).

Drilling and seismic imaging of the subduction inputs into the Nankai Trough has illustrated a variety of sediment/tuffaceous/igneous assemblages that have only partly been sampled in drilling of the accretionary prism. The most significant of these sediment inputs include the following:

(1) Basaltic basement of the Shikoku Basin is overlain by Middle Miocene units of pelagic claystone and volcaniclastic beds (tuffs) associated with the anomalous near-trench Middle Miocene igneous activity in the outer zones of southwest Japan. These units were found in the Muroto transect and at Sites C0011 and C0012 (Fig. 4) (Taira et al., 1992; Moore et al., 2001; Pickering et al., 2013).

(2) A lower turbidite fan (the Kyushu Fan) of Middle to Late Miocene age widely found in depositional low-points in the Shikoku Basin (Ike et al., 2008) and sampled at Sites 1177, 297, C0011 and C0012 (Fig. 2) (Pickering et al., 2013). Detrital zircon ages indicate derivation at 9.4 Ma from sources in northern Honshu and the North China Craton but at 15.4 Ma include an additional source in the Yangtze craton (Clift et al., 2013) and are quartz-rich to quartzose sands (Fergusson, 2003).

(3) Late Miocene upper turbidite fans and sediment gravity deposits (the Zenisu fans) with volcaniclastic detritus and are considered to have been derived from the Honshu - IzuBonin-Marianas collision zone (Pickering et al., 2013). 
(4) Pleistocene to middle Miocene mud/mudstone of the Shikoku Basin succession are widely sampled at most sites (Fig. 4) (Moore et al., 2001; Underwood and Moore, 2012; Pickering et al., 2013). The upper part of this fine-grained succession contains common ash-fall layers which are absent from the lower part of the succession due to a lack of preservation as a result of thermal and diagenetic effects (Moore et al., 2001).

(5) Mainly Pleistocene trench-wedge turbidites (Sites C0006, C0007; Fig. 4) and slope basin deposits (Sites 1175, 1176; Fig. 4) derived from the southwest Japan magmatic arc and accretionary belts with lithic fragments dominated by sedimentary and low-grade metamorphic sedimentary rock fragments (Clift et al., 2013), but includes late Miocene trench-wedge turbidites preserved at Site 1178 (Fergusson, 2003).

(6) The modern to late Pleistocene trench-wedge in the Nankai Trough consisting of turbidites and axial channel deposits dominated by fresh mafic to intermediate volcanic rock fragments, feldspar and quartz, all derived from the Izu-Honshu collision zone (Underwood et al., 1993; Fergusson, 2003).

In summary, the turbidite and mudstone dominated units being accreted to the Nankai Trough accretionary prism have resulted in a substantial subduction complex that provides a suitable modern analogue for the accretionary units of the New England Orogen. What is apparent from this work is that the Nankai Trough accretionary prism now and in the future will consist of a variety of accreted assemblages with provenance reflecting diverse sources including northern Honshu and the Yangtze craton (Site 1177), ancient accretionary subduction complexes in southwest Japan (Sites 1176, C0006, C0007) and sources from the Izu-Honshu collision zone in central Japan (Sites C0011, C0012, 808, 1174). This variety of units in the Nankai Trough reflects the complicated tectonic history which undoubtedly has been somewhat simplified for the New England Orogen where the outboard oceanic palaeogeographic elements can only be inferred from units accreted to the Palaeozoic subduction complex.

\subsection{Accretionary belts of southwest Japan and the Kanto Syntaxis}

In this section, the accretionary belts of southwest Japan (Fig. 4) are briefly reviewed; these belts provide the marker units for the Kanto Syntaxis, an example of an orocline developed in an accretionary belt and considered at least partly related to collision with the Izu-BoninMarianas arc indentor.

Major episodes of accretionary growth in southwest Japan are recognised in the Permian (Akiyoshi), Jurassic (Mino-Tanba), Cretaceous to mid Neogene (Shimanto), and show relatively straightforward growth southwards (Isozaki et al., 2010; Wakita, 2013). Accretionary development of subduction complexes is well illustrated by the structural repetition of ocean plate and trench wedge turbidite assemblages with widespread development of MORB, ocean island basalt, pelagic and shallow marine limestone, and deepmarine radiolarian chert (Isozaki et al., 1990; Wakita, 2013). Radiolarian microfossils have been utilised in many parts of these accretionary belts to demonstrate subduction and accretion of long-lived oceanic plates with histories >50 Ma (Matsuda and Isozaki, 1991; Wakita and Metcalfe, 2005; Wakita, 2012, 2013). Complications include development of paired metamorphic belts with the Early Cretaceous couple (Sanbagawa and Ryoke belts) and the Late Cretaceous couple (Shimanto high-P metamorphic belt and the San-in belt in inner southwest Japan) interspersed with low-grade accretionary complexes (Isozaki et al., 2010). More problematic are relationships between the Jurassic accretionary complex and the intervening Kurosegawa zone, which includes a variety of Palaeozoic to Mesozoic 
metamorphic assemblages with abundant serpentinite that includes Cambrian blueschist blocks derived from MORB basalt (Yang et al., 2016). The Kurosegawa zone has been variously interpreted as either a low-angle thrust sheet lying on the underlying Jurassic accretion complex (Isozaki et al., 2010) or alternatively as a significant strike-slip fault zone with derivation from the South Kitakami Block in northeast Japan (Kato and Saka, 2003).

The Kanto Syntaxis is the prominent curve in the Shimanto, Sanbagawa, Ryoke and MinoTanba belts around the Izu-Honshu collision zone in central Japan (Fig. 4) that is considered at least partly caused by the collision, although this has been a subject of continuing debate (Amano, 1991; Takahashi and Saito, 1997; Kimura et al., 2014). Palaeomagnetic data collected from rocks around the Kanto Syntaxis by Takahashi and Saito (1997) and Hoshi and Sano (2013) show that formation of the syntaxis was not solely a result of impingement of the accretionary belts by the Izu-Bonin-Marianas arc indentor. Opening of the Sea of Japan in the early Miocene was achieved by a $50^{\circ}$ clockwise rotation of southwest Japan from a NNE to an ENE trend (Faure and Lalevée, 1987), thus the western limb of the syntaxis was originally NNE trending (Takahashi and Saito, 1997), although data presented by Hoshi and Sano (2013) indicate that this limb has undergone a $20^{\circ}$ anticlockwise rotation associated with the Izu-Honshu collision at 17.5-15 Ma. A 40-50 clockwise rotation of the eastern limb of the syntaxis in the Kanto Mountains was suggested based on palaeomagnetic data at $\sim 15 \mathrm{Ma}$, and was followed by continuing rotation until $6 \mathrm{Ma}$, which was suggested to be associated with the collision (Takahashi and Saito, 1997). Smaller-scale flexures occur in Shimanto belt rocks in Cape Ashizuru and Cape Muroto along the southern side of Shikoku Island and the Kii Peninsula in Honshu and are considered caused by impingement of subducting seamounts (Fig. 4) (Hibbard et al., 1992; Kimura et al., 2014).

In summary, the Kanto Syntaxis provides the largest example of an orocline in the accretionary belts of southwest Japan and is considered partly caused by indentation of the Izu-Bonin-Marianas arc in the mid Miocene arc collision. Most of the accretionary belts of Mesozoic to Cenozoic age are affected by the Kanto Syntaxis (Fig. 4) which has a structure similar to that of the Texas Orocline of the southern New England Orogen.

\section{Discussion}

\subsection{Accretionary development of the southern New England Orogen}

Accretionary development of the southern New England Orogen is outlined using insights gained from accretionary belts of southwest Japan and the Nankai Trough. This accretionary development provides the background for understanding initiation of the Texas and Coffs Harbour oroclines.

The subduction complex of the southern New England Orogen can be divided into three major components: (1) upper Silurian to probable Upper Devonian chert and mudstone dominant units forming a marker east of the Peel Fault, (2) the probable Silurian to Lower Devonian arc to backarc unit of the Texas and Coffs Harbour oroclines, and (3) dominantly Carboniferous units with abundant trench-wedge turbidites that are widespread in much of the Tablelands Complex (including the Sandon association, Texas beds, and Coffs Harbour association, see Supplementary data). The Devonian accretionary units of the southern New England Orogen are atypical for subduction complexes with the dominance of fine-grained rocks and associated island arc volcanics in the Silverwood Group in comparison to turbidite- 
dominant accretionary units in subduction complexes (Kusky et al., 2013). Note that similar island arc units have been accreted in the Honshu - Izu-Bonin-Marianas arc collision zone in the core of the Kanto Syntaxis (Niitsuma, 1989; Amano, 1991).

Devonian reconstructions of the southern New England Orogen have an east-facing continental margin/island arc with the Devonian Tamworth Group in the Tamworth Belt representing the arc and the Woolomin Group the adjacent subduction complex (Leitch, 1975; Cawood, 1983; Cawood and Leitch, 1985). The age of the Woolomin Group, overlapping with the timing of the mafic to intermediate volcanic and volcaniclastic successions of the Tamworth Belt (Aitchison and Flood, 1992; Offler and Murray, 2011), and the lack of any preserved forearc basin between the inferred arc and subduction complex in the Early to early Late Devonian have always been problematic for this model. In an alternative model, the Gamilaroi terrane (pre-mid Late Devonian units of the Tamworth Belt) was a west-facing island arc (Aitchison and Flood, 1995). The setting of the Woolomin Group was not specified in this model and is considered herein to have formed in a backarc basin to the east of the west-facing island arc and subsequently was accreted along a newly formed west-dipping subduction zone in the mid-Late Devonian. Support for the west-facing island arc concept is given by the geochemistry of Devonian volcanic rocks in the Tamworth Belt that are more arc-like chemistry to the west and a more rifted back-arc chemistry to the east (Offler and Murray, 2011).

The Woolomin Group is dominated by fine-grained rocks and in contrast to most subduction complexes lack significant trench-wedge deposits (Isozaki et al., 1990, 2010; Matsuda and Isozaki, 1991; Kusky et al., 2013), as are characteristic of the Sandon and Coffs Harbour associations (Fergusson, 1985, 2010). The ocean plate stratigraphy, based on palaeontological data for the Bobs Creek Formation of the Woolomin Group (see Supplementary data), indicates an oceanic setting with the Late Silurian to late Middle Devonian age range (Aitchison and Flood, 1992; Vickery et al., 2010) consistent with development of a relatively small ocean basin, potentially a backarc basin (e.g., Matsuda and Isozaki, 1991). The Devonian Silverwood Group and Willowie Creek beds are anomalous in terms of their location west of the folded northern continuation of the Peel Fault around the Texas orocline (see above). Both units have a backarc to rifted island arc setting (Murray et al., 1987; van Noord, 1999) and presumably both the Willowie Creek rocks and the Silverwood Group were deformed as major fault slices as subduction flipped and a new subduction zone initiated in the former extended island arc - backarc basin. Development of major thrust slices in the Silverwood Group and Willowie Creek beds are analogous to the major fault slices in central Japan formed by accretion of the Izu-Bonin-Marianas arc during collision with the Honshu arc (Niitsuma, 1989; Amano, 1991).

In the Carboniferous, the styles of accretionary units are typical of subduction complexes with the dominance of volcaniclastic turbidites and less abundant oceanic stratigraphy as outlined above (see Supplementary data). The lithological and structural styles of these units have much in common with the accretionary subduction complexes of Japan, including the Mino-Tanba belt, and the Shimanto belts (Isozaki et al., 1990, 2010). There are several significant along strike variations that occur in the subduction complex in the Carboniferous. The Texas Orocline is notable for the abundance of limestone in the core of the structure and along both limbs including the Ashford Limestone (Fig. 5). These rocks are associated with more abundant and larger masses of altered mafic volcanic rocks than encountered in either the southern Tablelands Complex or in the Coffs Harbour Block. As indicated above, these 
rocks are interpreted as being related to accretion and subduction of a seamount chain (Buchs et al., 2010).

In summary, the accretionary history of the southern New England Orogen consists of two distinct phases. In the Devonian a west-facing island to backarc basin assemblage was accreted to the eastern Gondwana active margin resulting in formation of island arc basement to the Tamworth Belt (Gamilaroi terrane) (Aitchison and Flood, 1995; Offler and Murray, 2011) and accretionary units in the northern and southern Tablelands Complex (Silverwood association and Woolomin Group respectively). In the Carboniferous, as has been long recognised in the literature (Fergusson, 1984; Aitchison et al., 1992), a more typical Japanstyle subduction complex developed with accretion of turbidite dominated units as also found by the widespread drilling in the Nankai Trough.

\subsection{Relationships of oroclines to accretion and other processes}

The southern New England Orogen has been considered a "spectacularly contorted orogenic structure" (Rosenbaum, 2012) but the causes for the formation of these oroclines has been much debated (e.g. Murray et al., 1987; Cawood et al., 2011a, b; Rosenbaum et al., 2012; Shaanan et al., 2015a, b; Phillips et al., 2016). Here the initiation of the Texas and Coffs Harbour oroclines is related to impingement of an oceanic topographic feature on the subducting plate during the second accretionary phase of the southern New England Orogen, which was not considered in previous explanations.

The association of the core and parts of limbs of the Texas orocline Orocline with limestone occurrences is unusual and distinctive compared to the Manning Orocline, and in particular, the Coffs Harbour Orocline. As discussed above these limestones are interpreted as a result of the accretion of seamounts but given their extent, are probably related to subduction of a seamount chain (Buchs et al., 2010). Impingement of such a feature on the developing accretionary prism is suggested here to have initiated oroclinal folding in the subduction complex as is evident in the Cenozoic Shimanto belt in the Muroto and Ashizuri peninsulas (Kimura et al., 2014) and also is more fully developed in the Kanto Syntaxis associated with the Izu-Bonin-Marianas indentor (Takahashi and Saito, 1997). Palaeomagnetic constraints on orocline development allow initiation of the Texas Orocline prior to the Permian as well as tightening and continued development postdating deposition of the Lower Permian outliers of the Texas Orocline (Aubourg et al., 2004; Li et al., 2012; Campbell et al., 2015).

Oroclinal development predated intrusions and associated volcanic rocks of the New England Batholith, which formed from 260 Ma onwards (Rosenbaum et al., 2012). The

palaeomagnetic data only give an upper limit to the duration of oroclinal folding and some of the data presented by Aubourg et al. (2004) indicate some rotation prior to the Permian. This is consistent with the suggestion herein that the variations in the accretionary units reflect differences in accretionary styles with subduction of a seamount chain providing an initiation point for formation of the Texas Orocline (Fig. 9). More recently acquired palaeomagnetic data has only been able to show that oroclinal folding must have formed prior to the mid Permian change from extension to contraction at 272 Ma (Shaanan et al., 2015a) but no further constraint on initiation of the oroclines was given. 
(a)

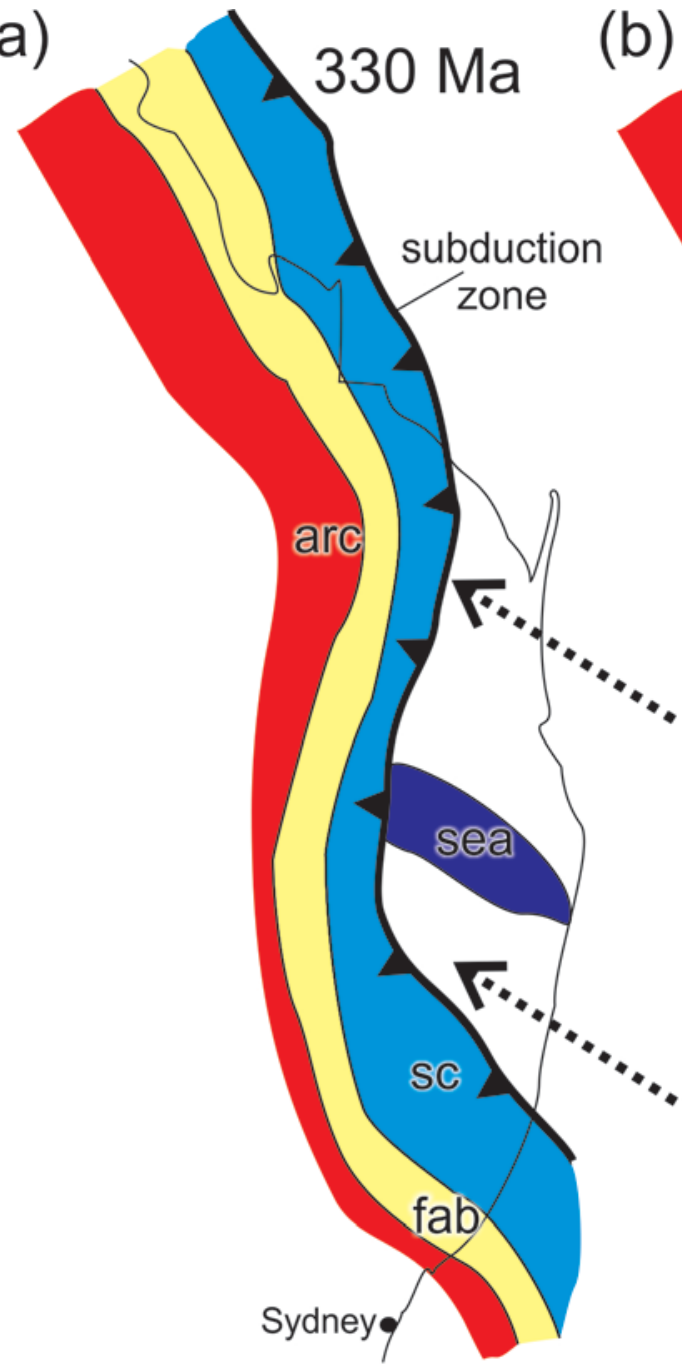

(b)

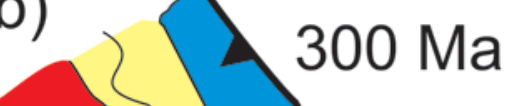

\subduction

zone

0

$400 \mathrm{~km}$

Fig. 9. Proposed initiation of the Texas orocline by the subduction of a seamount chain in the mid Carboniferous (a) followed by further development with continuing subduction (b).

Based in part on the models of Cawood et al. (2011a, b) and Phillips et al. (2016). Dashed arrows indicate direction of plate convergence. Abbreviatons: fab - forearc basin, sea seamount chain, sc - subduction complex.

Subsequent Early Permian development of the Texas and Coffs Harbour oroclines and formation of the Manning Orocline accompanying sinistral offset and rotation of the Hastings Block as outlined by Phillips et al. (2016), which is similar to block rotations about a vertical axis of the Hastings and Nambucca blocks suggested by Fielding et al. (2016) and White et al. (2016). Generally, oroclinal development in the southern New England Orogen has been related to several factors including: seamount/oceanic plateau impingement on the subduction complex during subduction accretion (herein), nucleation of oroclines on original bends in the convergent margin (Cawood et al., 2011b; Phillips et al., 2016), strike-slip faulting accompanying buckling of the orogenic belt (Murray et al., 1987), and rollback induced extension in a backarc basin setting (Rosenbaum, 2012; Rosenbaum et al., 2012; Shaanan et al., 2015a, b). It is conceivable that most, if not all of these factors, have played some role in the development of the New England oroclines. Orocline development must have overlapped with widespread S-type plutonism, thick basinal sedimentation, mafic volcanism and high temperature low pressure metamorphism, consistent with a backarc setting, in the Early 
Permian (Rosenbaum et al., 2012; Shaanan et al., 2014, 2015a, b). Comparisons with formation of Mediterranean-type oroclines and curved island arcs in the western Pacific have been made by these authors. Thus rollback must have played some role, but this role should not been be overstated as the extensional basin that developed associated with Early Permian development of the Sydney-Bowen Basin is considered a continental rift (Krassay et al., 2009). This contrasts with widespread new oceanic basement generated on the inner sides of oroclines associated with rollback as in the western Mediterranean Sea (Rosenbaum, 2014).

In summary, the Texas Orocline was initiated by indentation of a seamount chain into its hinge region and this also resulted in development of the accompanying Coffs Harbour Orocline. Rollback in Early Permian orocline development for the southern New England Orogen must have played some role (e.g. Rosenbaum et al., 2012; Shaanan et al., 2015a, b) but the lack of oceanic marginal sea development west of the Texas and Manning oroclines implies that this role was somewhat limited.

\section{Conclusions}

This study was undertaken to resolve the initiation of oroclinal bending in the Texas and Coffs Harbour oroclines of the southern New England Orogen. These oroclines have most recently been related to rollback in the Early Permian affecting the backarc setting at this time (e.g. Rosenbaum et al., 2012). Comparison with Japanese examples including the Kanto Syntaxis and smaller-scale flexures in the accretionary rocks of southwest Japan has resulted in the following conclusions.

(1) The Texas Orocline was nucleated by the impingement of a seamount chain on the subducting plate as it collided with accreted turbidites during Carboniferous subduction. Relicts of the seamount chain include Visean limestones and associated ocean island basalts that abound amongst accreted turbidites in the core of the indented Texas Orocline but are missing from the adjacent Coffs Harbour Orocline.

(2) As argued by previous authors (e.g. Rosenbaum et al., 2012; Shaanan et al., 2015a), rollback has played a role in development of these oroclines but the lack of oceanic crust generated on the inner sides of these oroclines is problematic for the rollback scenario and it is argued here that the role of hinge retreat in ongoing orocline development has been overstated.

(3) As widely recognised, accretionary development of the subduction complex of the southern New England Orogen was dominated by a phase of Carboniferous accretion of abundant trench-wedge deposits (e.g. Fergusson, 1984; Aitchison et al., 1992), but as argued here included nucleation of the major Z-shaped Texas and Coffs Harbour oroclines. An earlier episode of accretion of arc-backarc deposits in the Devonian are now considered to have formed large thrust slices comparable those of the Honshu - IzuBonin-Marianas collision zone of central Japan. The Woolomin Group with its widespread chert-mudstone rocks is considered herein to have formed in a backarc basin east of the Devonian island arc. Previous authors recognised accretion of a west-facing island arc in the Late Devonian that now forms basement to the Carboniferous forearc basin (Aitchison and Flood, 1995; Offler and Murray, 2011) but the significance of the Woolomin Group was not considered in these earlier models.

\section{Acknowledgements}

Simon Williams (EarthByte, School of Geosciences, University of Sydney) kindly provided valuable advice and references on the motion of the Philippine Sea plate. I have engaged in 
numerous discussions with Evan Leitch on the southern New England Orogen and subduction in general. He also kindly read and commented on a draft of the manuscript. His comments and experience are greatly appreciated. I have benefited from discussions with Sol Buckman, Gary Colquhoun and many other geologists and geophysicist working in eastern Australia and Japan too numerous to mention over many years. Research support has been provided by the University of Wollongong and the GeoQuEST Research Centre. The manuscript was much improved after major revisions based on a detailed review by Dr Uri Shaanan and significant editorial advice from Professor Irina Artemieva. The comments of an anonymous reviewer are also gratefully acknowledged.

\section{References}

Aitchison, J.C., 1988. Late Paleozoic radiolarian ages from the Gwydir terrane, New England orogen, eastern Australia. Geology 16, 793-795.

Aitchison, J.C., Blake, M.C., Flood, P.G., Murchey, B.L., 1988. New and revised lithostratigraphic units from the southwestern New England Fold Belt. Quarterly Notes of the Geological Survey of New South Wales, 72, 10-16.

Aitchison, J.C., Blake, M.C., Flood, P.G., Jayko, A.S., 1994. Paleozoic ophiolitic assemblages within the southern New England Orogen of eastern Australia; implications for growth of the Gondwana margin. Tectonics 13, 1135-1149.

Aitchison, J.C. and Flood, P.G., 1992. Implications of radiolarian research for analysis of subduction complex terranes in the New England Orogen, NSW, Australia. Palaeogeography, Palaeoclimatology, Palaeoecology 96, 89-102.

Aitchison, J.C., Flood, P.G., Spiller, F.C.P., 1992. Tectonic setting and paleoenvironment of terranes in the southern New England Orogen as constrained by radiolarian biostratigraphy. Palaeogeography, Palaeoclimatology, Palaeoecology 93, 31-54.

Aitchison, J., Ireland, T.R., 1995. Age profile of ophiolitic rocks across the late Palaeozoic New England Orogen, New South Wales; implications for tectonic models. Australian Journal of Earth Sciences 42, 11-23.

Aitchison, J.C., Flood, P.G., 1995. Gamilaroi Terrane: a Devonian rifted intra-oceanic islandarc assemblage, NSW, Australia. In: Smellie, J.L. (Ed.), Volcanism Associated with Extension at Consuming Plate Margins: Geological Society of London Special Publication, 81, pp. 155-168.

Amano, K., 1991. Multiple collision tectonics of the South Fossa Magna in central Japan. Modern Geology 15, 315-329.

Amante, C., Eakins, B.W., 2009. ETOPO1 1 Arc-Minute Global Relief Model: Procedures, Data Sources and Analysis. NOAA Technical Memorandum NESDIS NGDC-24. National Geophysical Data Center, NOAA. doi:10.7289/V5C8276M.

Aubourg, C., Klootwijk, C., Korsch, R.J., 2004. Magnetic fabric constraints on oroclinal bending of the Texas and Coffs Harbour blocks: New England Orogen, eastern Australia. In: Martin-Hernandez , F., Luneburg, C.M., Aubourg, C., Jackson, M. (Eds.), Magnetic fabric: methods and applications. Geological Society of London Special Publication 238, 421-445.

Babaahmadi, A., Rosenbaum, G., 2013. Kinematics of the Demon Fault: implications for Mesozoic dextral strike-slip faulting in eastern Australia. Australian Journal of Earth Sciences 60, 255-269.

Bahlburg, H., Vervoort, J.D., Du Frane, S.A., Bock, B., Augustsson, C., 2009. Timing of accretion and crustal recycling at accretionary orogens: insights learned from the western margin of South America. Earth-Science Reviews 97, 227-253. 
Bajolet, F., Replumaz, A., Lainé, R., 2013. Orocline and syntaxes formation during subduction and collision. Tectonics, 32, 1529-1546.

Brooke-Barnett, S., Rosenbaum, G., 2015. Structure of the Texas Orocline beneath the sedimentary cover (southeast Queensland, Australia). Australian Journal of Earth Sciences 62, 425-445.

Brown, R.E., 2001. Peel Discovery 200 Geophysics - Providing keys to exploration in the western New England region of New South Wales. Quarterly Notes of the New South Wales Geological Survey 111, 16 p.

Brown, R.E., 2003. Peel South Exploration NSW geophysics - interpretation of new data for exploration and geological investigations in the western New England area of New South Wales. Quarterly Notes of the Geological Survey of New South Wales 114, 28 p.

Brown, R.E., 2009. The newly defined Glen Bell Formation, and a reappraisal of the Wisemans Arm Formation, Halls Creek district, northern NSW. Quarterly Notes of the Geological Survey of New South Wales 114, 22 p.

Buchs, D.M., Flood, P.G., Arculus, R.J., Aitchison, J.C., 2010. Value of accreted oceanic islands in deciphering the convergent margin evolution of eastern Australia. In: Buckman, S., Blevin, P.L. (Eds.), New England Orogen 2010. Proceedings of a conference held at the University of New England, Armidale, New South Wales, Australia, November 2010, 106-111.

Buckman, S., Nutman, A.P., Aitchison, J.C., Parker, J., Bembrick, S., Line, T., Hidaka, H., Kamiichi, T., 2015. The Watonga Formation and Tacking Point Gabbro, Port Macquarie, Australia: Insights into crustal growth mechanisms on the eastern margin of Gondwana. Gondwana Research 28, 133-151.

Campbell, M., Rosenbaum, G., Shaanan, U., Fielding, C. R., Allen, C., 2015. The tectonic significance of lower Permian successions in the Texas Orocline (Eastern Australia). Australian Journal of Earth Sciences 62, 789-806.

Carey, S.W., 1955. The orocline concept in geotectonics, Part I. Papers and Proceedings of the Royal Society of Tasmania 89, 255-288.

Cawood, P.A., 1983. Modal composition and detrital clinopyroxene geochemistry of lithic sandstones from the New England Fold Belt (east Australia): A Paleozoic forearc terrane. Geological Society of America Bulletin 94, 1199-1214.

Cawood, P.A., 2005. Terra Australis Orogen: Rodinia breakup and development of the Pacific and Iapetus margins of Gondwana during the Neoproterozoic and Paleozoic. Earth-Science Reviews 69, 249-279.

Cawood, P.A., Leitch, E.C., 1985. Accretion and dispersal tectonics of the southern New England Fold Belt, eastern Australia. In: Howell, D.G. (Ed.), Tectonostratigraphic Terranes of the Circum-Pacific Region, volume 1. Circum-Pacific Council of Energy and Mineral Resources, 481-492.

Cawood, P.A., Leitch, E.C., Merle, R.E., Nemchin, A.A., 2011a. Orogenesis without collision: stabilizing the Terra Australis accretionary orogen, eastern Australia. Geological Society of America Bulletin 123, 2240-2255.

Cawood, P.A., Pisarevsky, S.A., Leitch, E.C., 2011b. Unraveling the New England orocline, east Gondwana accretionary margin. Tectonics 30, TC5002. http://dx.doi.org/10.1029/2011tc002864 .

Cayley, R.A., 2012. Oroclinal folding in the Lachlan Fold Belt: Consequence of southeastdirected Siluro-Devonian subduction rollback superimposed on an accreted Ordovician arc assemblage in eastern Australia. Selwyn Symposium 2012. Geological Society of Australia Abstracts 103, 34-43. 
Clift, P. D., Carter, A., Nicholson, U., Masago, H., 2013. Zircon and apatite thermochronology of the Nankai Trough accretionary prism and trench, Japan: Sediment transport in an active and collisional margin setting. Tectonics 32, 377-395.

Corbett, G.J., 1976. A new fold structure in the Woolomin beds suggesting a sinistral movement on the Peel fault. Australian Journal of Earth Sciences 23, 401-406.

de Wit, M., Jeffery, M., Bergh, H., Nicolaysen, L., 1988. Geological map of sectors of Gondwana reconstructed to their positions $\sim 150 \mathrm{Ma}$, scale 1:10,000,000. American Association of Petroleum Geologists, Tulsa, Oklahoma.

Dirks, P.H.G.M., Hand, M., Collins, W.J., Offler, R., 1992. Structural-metamorphic evolution of the Tia Complex, New England Fold Belt; thermal overprint of an accretionsubduction complex in a compressional back-arc setting. Journal of Structural Geology 14, 669-688.

Donchak, P.J.T., Bultitude, R.J., Purdy, D.J., Denaro, T.J., 2007. Geology and mineralisation of the Texas Region, south-eastern Queensland. Geological Survey of Queensland, Queensland Geology 11, 95 p.

Donchak, P.J.T.., Purdy, D.J., Withnall, I.W., Blake, P.R., Jell, P.A., 2013. Chapter 5 New England Orogen. In: Jell, P.A. (Ed.), The Geology of Queensland. Geological Survey of Queensland, Brisbane, Queensland, 305-472.

Faure, M., Lalévee, F., 1987. Bent structural trends of Japan: Flexural slip folding related to the Neogene opening of the Sea of Japan. Geology 15, 49-52.

Fergusson, C.L., 1982. Structure of the Late Palaeozoic Coffs Harbour Beds, northeastern New South Wales. Journal of the Geological Society of Australia 29, 25-40.

Fergusson, C.L., 1984. Tectonostratigraphy of a Palaeozoic subduction complex in the central Coffs Harbour Block of northeastern New South Wales. Australian Journal of Earth Sciences 31, 217-236.

Fergusson, C.L., 1985. Trench-floor sedimentary sequences in a Palaeozoic subduction complex, eastern Australia. Sedimentary Geology 42, 181-200.

Fergusson, C.L., 2003. Provenance of Miocene-Pleistocene turbidite sands and sandstones, Nankai Trough, Ocean Drilling Program Leg 190. In: Mikada, H., Moore, G.F. Taira, A., Becker, K., Moore, J.C., Klaus, A. (Eds.), Proceedings of the Ocean Drilling Program, Scientific Results190/196, Ocean Drilling Program, College Station, Texas, $1-28$.

Fergusson, C.L., 2010. Interpreting New England subduction complex rocks using deep-sea drilling results from the Nankai Trough (offshore southwest Japan). In: Buckman, S., Blevin, P.L. (Eds.), New England Orogen 2010. Proceedings of a conference held the University of New England, Armidale, New South Wales, Australia, November 2010, 149-155.

Fergusson, C.L., Flood, P.G., 1985. A Late Palaeozoic subduction complex in the Border Rivers area of southeast Queensland. Proceedings of the Royal Society of Queensland 95, 47-55.

Fielding, C. R., Shaanan, U., Rosenbaum, G., 2016. Sedimentological evidence for rotation of the Early Permian Nambucca block (eastern Australia). Lithosphere 8, 684-698.

Flood, P.G., Aitchison, J.C., 1992. Late Devonian accretion of the Gamilaroi Terrane to eastern Gondwana: Provenance linkage suggested by the first appearance of Lachlan Fold Belt-derived quartzarenite. Australian Journal of Earth Sciences 39, 539-544.

Glen, R.A., 2013. Refining accretionary orogen models for the Tasmanides of eastern Australia. Australian Journal of Earth Sciences 60, 315-370.

Gulick, S.P.S., Bangs, N.L., Shipley, T.H., Nakamura, Y., Moore, G.F., Kuramoto, S., 2004. 3-D architecture of the Nankai accretionary prism's imbricate thrust zone off Cape 
Muroto, Japan: En echelon thrust accommodation of along strike stress regime changes: Journal of Geophysical Research 109, p. B02105, doi: 10.1029/2003JB002654.

Hall, R., 2002. Cenozoic geological and plate tectonic evolution of SE Asia and the SW Pacific: computer-based reconstructions and animations. Journal of Asian Earth Sciences 20, 353-434.

Hibbard , J.P., Karig, D.E., 1990. Structural and magmatic responses to spreading ridge subduction: an example from southwest Japan. Tectonics 9, 207-230.

Hibbard, J., Karig, D., Taira, A., 1992. Anomalous evolution of the Shimato Accretionary Prism at Murotomisaki, Shikoku Island, Japan. Island Arc 1, 133-147.

Hoshi, H., Sano, M., 2013. Paleomagnetic constraints on Miocene rotation in the central Japan Arc. Island Arc 22, 197-213.

Hoy, D., Rosenbaum, G., Wormald, R., Shaanan, U., 2014. Geology and geochronology of the Emu Creek Block (northern New South Wales, Australia) and implications for oroclinal bending in the New England Orogen. Australian Journal of Earth Sciences 61, 1109-1124.

Ike, T., Moore, G.F., Kuramoto, S., Park, J.-O., Kaneda, Y., Taira, A., 2008. Variations in sediment thickness and type along the northern Philippine Sea Plate at the Nankai Trough. Island Arc 17, 342-357.

Isozaki, Y., Maruyama, S., Furuoka, F., 1990. Accreted oceanic materials in Japan. Tectonophysics 181, 179-205.

Isozaki, Y., Aoki, K., Nakama, T., Yanai, S., 2010. New insight into a subduction related orogen: a reappraisal of the geotectonic framework and evolution of the Japanese Islands. Gondwana Research 18, 82-105.

Jolivet, L., Tamaki, K., Fournier, M., 1994. Japan Sea, opening history and mechanism: A synthesis. Journal of Geophysical Research 99, 22,237-22,259.

Kato, K., Saka, Y., 2003. Kurosegawa Terrane as a Transform Fault Zone in Southwest Japan. Gondwana Research 6, 669-686.

Kimura, J.-I., Stern, R.J., Yoshida, T., 2005. Reinitiation of subduction and magmatic responses in SW Japan during Neogene time. Geological Society of America Bulletin 117, 969-986.

Kimura, G., Hashimoto, Y., Kitamura, Y., Yamaguchi, A., Koge, H., 2014. Middle Miocene swift migration of the TTT triple junction and rapid crustal growth in southwest Japan: A review. Tectonics 33, 1219-1238.

Korsch, R.J., 1977. A framework for the Palaeozoic geology of the southern part of the New England Geosyncline. Journal of the Geological Society of Australia 24, 339-355.

Korsch, R.J., 1978a. Stratigraphic and igneous units in the Rockvale-Coffs Harbour region, northern New South Wales. Journal and Proceedings of the Royal Society of New South Wales 111, 13-17.

Korsch, R. J., 1978b. Petrographic variations within thick turbidite sequences: an example from the late Palaeozoic of eastern Australia. Sedimentology, 25, 247-265.

Korsch, R.J., 1981a. Some tectonic implications of sandstone petrofacies in the Coffs Harbour Association, New England Orogen, New South Wales. Journal of the Geological Society of Australia 28, 261-269.

Korsch, R.J., 1981b. Deformational history of the Coffs Harbour Block. Journal and Proceedings of the Royal Society of New South Wales 114, 17-22.

Korsch, R.J., 1993. Reconnaissance geology of the Solitary Islands: Constraints on the geometry of the Coffs Harbour orocline. In: Flood, P.G., Aitchison, J.C. (Eds.), New England Orogen, eastern Australia. Department of Geology and Geophysics, University of New England, Armidale, New South Wales, 265-274. 
Korsch, R. J., Adams, C. J., Black, L. P., Foster, D. A., Fraser, G. L., Murray, C. G., Foudoulis, C., Griffin, W. L., 2009. Geochronology and provenance of the Late Paleozoic accretionary wedge and Gympie Terrane, New England Orogen, eastern Australia. Australian Journal of Earth Sciences, 56, 655-685.

Krassay, A.A., Korsch, R.J., Drummond, B.J., 2009. Meandarra Gravity Ridge: symmetry elements of the gravity anomaly and its relationship to the Bowen-Gunnedah-Sydney basin system. Australian Journal of Earth Sciences 56, 355-379.

Kusky, T.M., Windley, B.F., Safonova, I., Wakita, K., Wakabayashi, J., Polat, A., Santosh, M., 2013. Recognition of ocean plate stratigraphy in accretionary orogens through Earth history: A record of 3.8 billion years of sea floor spreading, subduction, and accretion. Gondwana Research 24, 501-547.

Leitch, E.C., 1974. The geological development of the southern part of the New England Fold Belt. Journal of the Geological Society of Australia 21, 133-156.

Leitch, E.C. 1975. Plate tectonic interpretation of the Paleozoic history of the New England Fold Belt. Geological Society of America Bulletin 86, 141-144.

Leitch, E.C., Asthana, 1985. The geological development of the Thora district, northern margin of the Nambucca Slate Belt, eastern New England Fold Belt. Proceedings of the Linnean Society of New South Wales 108, 119-140.

Li, P., Rosenbaum, G., 2014. Does the Manning Orocline exist? New structural evidence from the inner hinge of the Manning Orocline (eastern Australia). Gondwana Research 25, 1599-1613.

Li, P., Rosenbaum, G., Donchak, P.J.T., 2012. Structural evolution of the Texas Orocline, eastern Australia. Gondwana Research 22, 279-289.

Li, P., Rosenbaum, G., Vasconcelos, P., 2014. Chronological constraints on the Permian geodynamic evolution of eastern Australia. Tectonophysics 617, 20-30.

Lennox, P.G., Flood, P.G., 1997. Age and structural characterisation of the Texas megafold, southern New England Orogen, eastern Australia. In: Ashley, P.M., Flood, P.G. (Eds.), Tectonics and Metallogenesis of the New England Orogen: Alan H. Voisey Memorial Volume. Geological Society of Australia Special Publication 19, 161-177.

Mahony, S., Wallace, L., Miyoshi, M., Villamor, P., Sparks, R., Hasenaka, T., 2011. Volcano-tectonic interactions during rapid plate-boundary evolution in the Kyushu region, SW Japan, Geological Society of America Bulletin 123, 2201-2223.

Matsuda, T., Isozaki, Y., 1991. Well-documented travel history of Mesozoic pelagic cherts in Japan: from remote ocean to subduction zone. Tectonics 10, 475-499.

Mochales, T., Rosenbaum, G., Speranza, F., Pisarevsky, S.A., 2014. Unraveling the geometry of the New England oroclines (eastern Australia): constraints from magnetic fabrics. Tectonics 33, 2261-2282

Moore, G.F., Shipley, T.H., Stoffa, P.L., Karig, D.E., Taira, A., Kuramoto, S., Tokuyama, H., Suyehiro, K., 1990. Structure of the Nankai Trough accretionary zone from multichannel seismic reflection data. Journal of Geophysical Research 95, 8753-8765.

Moore, G.F., Taira, A., Klaus, A., Becker, L., Boeckel, B., Cragg, B.A., Dean, A., Fergusson, C.L., Henry, P., Hirano, S., Hisamitsu, T., Hunze, S., Kastner, M., Maltman, A.J., Morgan, J.K., Murakami, Y., Saffer, D.M., Sanchez-Gomez, M., Screaton, E.J., Smith, D.C., Spivack, A.J., Steurer, J., Tobin, H.J., Ujiie, K., Underwood, M.B.,Wilson, M., 2001. New insights into deformation and fluid flow processes in the Nankai Trough Accretionary Prism: results of Ocean Drilling Program Leg 190. Geochemistry Geophysics Geosystems 22001GC000166.

Moore, G.F., Bangs, N.L., Taira, A., Kuramoto, S., Pangborn, E., Tobin, H.J., 2007. Three dimensional splay fault geometry and implications for tsunami generation. Science 318, 1128-1131. 
Moore, G.F., Park, J.O., Bangs, N.L., Gulick, S.P., Tobin, H.J., Nakamura, Y., Sato, S., Tsuji, T., Yoro, T., Tanaka, H., Uraki, S., Kido, Y., Sanada, Y., Kuramoto, S., Taira, A., 2009. In: Kinoshita, M., Tobin, H., Ashi, J., Kimura, G., Lallement, S., Screaton, E.J., Curewitz, D., Masago, H., Moe, K.T., the Expedition, 314/315/316 Scientists (Eds.), Structural and seismic stratigraphic framework of the NanTroSEIZE Stage 1 transect. Proceedings of the Integrated Ocean Drilling Program, vol. 314/315/316, pp. 1-46. doi:10.2204/iodp.proc.314315316.102.2009.

Moore, G.F., Saffer, D.M., Studer, M., Pisani, P.C., 2011. Structural restoration of thrusts at the toe of the Nankai Trough accretionary prism off Shikoku Island, Japan: Implications for dewatering processes. Geochemistry Geophysics Geosystems Q0AD12, doi:10.1029/2010GC003453.

Moresi, L., Betts, P.G., Miller, M.S., Cayley, R.A., 2014. Dynamics of continental accretion. Nature 508, 245-248.

Murray, C.G., Fergusson, C.L., Flood, P.G., Whitaker, W.G., Korsch, R.J., 1987. Plate tectonic model for the Carboniferous evolution of the New England Fold Belt. Australian Journal of Earth Sciences 34, 213-236.

Musgrave, R.J., 2015. Oroclines in the Tasmanides. Journal of Structural Geology, 80, $72-$ 98.

Niitsuma, N., 1989. Collision tectonics in the South Fossa Magna, central Japan. Modern Geology 14, 3-18.

Offler, R., Lennox, P.G., Phillips, G., Yan, J., 2015. Comment on: “does the Manning orocline exist? New structural evidence from the inner hinge of the Manning orocline (eastern Australia)” by Li, P., Rosenbaum, G., 2013. Gondwana Research 25, 1599e1613. Gondwana Research 27, 1686-1688.

Offler, R., Murray, C.S., 2011. Devonian volcanics in the New England Orogen: Tectonic setting and polarity. Gondwana Research, 19, 706-715.

Okino, K., Ohara, Y., Kasuga, S., Kato, Y., 1999. The Philippine Sea: new survey results reveal the structure and the history of the marginal basin. Geophysical Research Letters 26, 2287- 2290.

Otofuji, Y., Kambara, A., Matsuda, T., Nohda, S., 1994. Counterclockwise rotation of northeast Japan: Paleomagnetic evidence for regional extent and timing of rotation. Earth and Planetary Science Letters 121, 503-518.

Park, J.O., Moore, G.F., Tsuru, T., Kodaira, S., Kaneda, Y., 2003. A subducted oceanic ridge influencing the Nankai megathrust earthquake rupture. Earth and Planetary Science Letters 217, 77-84.

Pickering, K.T., Underwood, M.B., Saito, S., Naruse, H., Kutterolf, S., Scudder, R., Park, J.O., Moore, G.F., Slagle, A., 2013. Depositional architecture, provenance, and tectonic/eustatic modulation of Miocene submarine fans in the Shikoku Basin: results from Nankai Trough Seismogenic Zone Experiment. Geochemistry, Geophysics, Geosystems 14, 1722-1739.

Phillips, G., Robinson, J., Glen, R., Roberts, J., 2016. Structural inversion of the Tamworth Belt: Insights into the development of orogenic curvature in the southern New England Orogen, Australia. Journal of Structural Geology 86, 224-240.

Raymond, O.L., Liu, S., Gallagher, R., Zhang, W., Highet, L.M., 2012. Surface Geology of Australia 1:1 million scale dataset 2012 edition. Geoscience Australia, http://www.ga.gov.au/metadata-gateway/metadata/record/74619/

Rosenbaum, G., 2012. The oroclines of the southern New England Orogen, eastern Australia. Episodes 35, 187-194.

Rosenbaum, G., 2014. Geodynamics of oroclinal bending: Insights from the Mediterranean. Journal of Geodynamics 82, 5-15. 
Rosenbaum, G., Li, P., Rubatto, D., 2012. The contorted New England Orogen (eastern Australia): new evidence from U-Pb geochronology of early Permian granitoids. Tectonics 31, TC1006. http://dx.doi.org/10.1029/2011tc002960 .

Rosenbaum, G., Uysal, I.T., Babaahmadi, A., 2015. The Red Rock Fault zone (northeast New South Wales): kinematics, timing of deformation and relationships to the New England oroclines. Australian Journal of Earth Sciences 62, 409-423.

Sdrolias, M., Roest, W.R., Müller, R.D., 2004. An expression of Philippine Sea plate rotation: The Parece Vela and Shikoku Basins. Tectonophysics 394, 69-86.

Seton, M., Muller, R., Zahirovic, S., Gaina, C., Torsvik, T., Shephard, G., Talsma, A., Gurnis, M., Turner, M., Maus, S., Chandler, M., 2012. Global continental and ocean basin reconstructions since 200 Ma. Earth-Science Reviews 113, 212-270.

Shaanan, U., Rosenbaum, G., Li, P., Vasconcelos, P., 2014. Structural evolution of the Early Permian Nambucca Block (New England Orogen, eastern Australia) and implications for oroclinal bending. Tectonics 33, 1425-1443.

Shaanan, U., Rosenbaum, G., Pisarevsky, S., Speranza, F., 2015a. Paleomagnetic data from the New England Orogen (eastern Australia) and implications for oroclinal bending. Tectonophysics 664, 182-190.

Shaanan, U., Rosenbaum, G., Wormald, R., 2015b. Provenance of the Early Permian Nambucca block (eastern Australia) and implications for the role of trench retreat in accretionary orogens. Geological Society of America Bulletin 127, 1052-1063.

Shipboard Scientific Party, 2001. Leg 190 summary. In: Moore, G.F., Taira, A., Klaus, A., et al., Proceedings of the Ocean Drilling Program, Initial Reports 190: College Station, Texas (Ocean Drilling Program), 1-87. doi:10.2973/odp.proc.ir.190.101.2001

Taira, A., 2001. Tectonic evolution of the Japanese island arc system. Annual Reviews of Earth and Planetary Sciences 29, 109-134.

Taira A, Hill I, Firth J, Berner U, Burkmann W, et al., 1992. Sediment deformation and hydrogeology of the Nankai Trough accretionary prism: synthesis of shipboard results of ODP Leg 131. Earth and Planetary Sciences Letters 109, 431-450.

Takahashi, M., 1994. Miocene tectonic deformation of central Japan: Paleomagnetic evidence of intra-arc bending. Journal of Geojisica Internacional 33, 25-44.

Takahashi, M., Saito, K., 1997. Miocene intra-arc bending at an arc-arc collision zone, central Japan. Island Arc 6, 168-82.

Takahashi, M., Saito, K., 1999. Miocene intra-arc bending at an arc-arc collision zone, central Japan: Reply. Island Arc 8, 117-123.

Underwood, M. B., Moore, G. F., 2012. Evolution of sedimentary environments in the subduction zone of southwest Japan: recent results from the NanTroSEIZE Kumano transect. In: Busby, C., Azor, A. (Eds.), Tectonics of Sedimentary Basins: Recent Advances. Wiley-Blackwell, 310-326.

Underwood, M.B., Orr, R., Pickering, K., Taira, A., 1993. Provenance and dispersal patterns of sediments in the turbidite wedge of Nankai Trough. In: Hill, I.A., Taira, A., Firth, J.V., et al., Proceedings of the Ocean Drilling Program, Scientific Results, 131: College Station, Texas, 15-34. doi:10.2973/odp.proc.sr.131.105.1993.

van Noord, K.A.A., 1999. Basin development, geological evolution and tectonic setting of the Silverwood Group. In: Flood, P.G. (Ed.), Regional Geology. Tectonics and Metallogenesis. New England Orogen. Earth Sciences, University of New England, Armidale, New South Wales, 163-180.

Vickery, N.M., Brown, R.E., Percival, I.G., 2010. Manilla 1:100,000 Geology Sheet 9036, Explanatory Notes. Geological Survey of New South Wales, Maitland, New South Wales, 176 p. https://search.geoscience.nsw.gov.au/product/653 
Wakita, K., 2012.Mappable features of mélanges derived from Ocean Plate Stratigraphy, in the Jurassic accretionary complexes of Mino and Chichibu terranes, Southwest Japan. Tectonophysics 568-569, 74-85.

Wakita, K., 2013. Geology and tectonics of Japanese Islands — a review — the key to understand the geology of Asia. Journal of Asian Earth Sciences 72, 75-87.

Wakita, K., Metcalfe, I., 2005. Ocean plate stratigraphy in East and Southeast Asia. Journal of Asian Earth Sciences 24, 670-702.

White, L., Rosenbaum, G., Allen, C.M., Shaanan, U., 2016. Orocline-driven transtensional basins: Insights from the Lower Permian Manning Basin (eastern Australia). Tectonics 35, 690-703.

Wu, J., Suppe, J., Lu, R., Kanda, R., 2016. Philippine Sea and East Asian plate tectonics since 52 Ma constrained by new subducted slab reconstruction methods. Journal of Geophysical Research Solid Earth 121, 4670-4741.

Yamazaki, T., Takahashi, M., Iryu, Y., Sato, T., Oda, M., Takayanagi, H., Chiyonobu, S., Nishimura, A., Nakazawa, A., Ooka, T., 2010. Philippine Sea Plate motion since the Eocene estimated from paleomagnetism of seafloor drill cores and gravity cores. Earth Planets Space 62, 495-502.

Yan, J., Lennox, P.G., Offler, R., 2016. History of faulting in the Northern Hastings Block, southern New England Orogen. Australian Journal of Earth Sciences 63, 821-841.

Yang, Q.-Y., Santosh, M., Maruyama, S., Nakagawa, M., 2016. Proto-Japan and tectonic erosion: Evidence from zircon geochronology of blueschist and serpentinite. Lithosphere 8, 386-395.

Zahirovic, S., Seton, M., Muller, R., 2014. The Cretaceous and Cenozoic tectonic evolution of Southeast Asia. Solid Earth 5, 227-273. 
Supplementary data

Accretionary units of the southern Tablelands Complex

More details are given below for the accretionary units of the southern Tablelands Complex which are important to resolving the existence of the Manning Orocline and also for comparative purposes to the units of the Texas and Coffs Harbour oroclines.

The Woolomin Group is dominated by fine-grained rocks consisting of chert, siliceous mudstone, and mudstone with less abundant metabasalt, conglomerate and pebbly mudstone and mapped along the eastern side of the Peel Fault (Fig. 5) (Aitchison et al., 1988, 1992; Brown, 2009; Vickery et al., 2010). It forms a distinctive marker and contrasts with the turbidite dominated units of the adjacent Wisemans Arm Formation and the accretionary complex units well to the east of the Peel Fault. Conodonts from chert indicate a Late Silurian age southeast of Tamworth (Ishiga et al., 1988) and overall the unit is generally considered Late Silurian to Middle Devonian (Vickery et al., 2010), although earlier radiolarian work indicated that the Woolomin Group extended into the Late Devonian (Aitchison et al., 1992). The Woolomin Group has been traced along the Peel Fault southwards around the Manning Orocline (Fig. 5). In this region, radiolarian ages of chert are Middle to Late Devonian consistent with the ages found in other parts of the Woolomin Group (Aitchison et al., 1992).

In some areas, the Woolomin Group has imbricated fault slices that repeat sections typical of ocean plate stratigraphy, with basal metabasalt, commonly pillowed, overlain by bedded chert and in turn overlain by mudstone, tuffaceous chert, and in some areas very limited lithic sandstone in turbidite units and/or conglomerates and pebbly mudstones with clasts of chert, sparse limestone and volcanic rocks (Cawood, 1982; Aitchison et al., 1988, 1992; Vickery et al., 2010). Elsewhere a multiply folded relatively coherent succession of distinctive bedded chert markers has been mapped (Blake and Murchey, 1988).

The Woolomin Group north of Tamworth has been subdivided into two formations (Fig. S1), the Nangahrah and Bobs Creek formations, both of similar lithological content (chert, basalt, mudstone, pebbly mudstone, conglomerate), although according to Brown (2009) and Vickery et al. (2010) the Bobs Creek Formation is poorer in chert compared to the Nangahrah Formation. Percival (in Vickery et al., 2010) on the basis of palaeontological data has concluded that the Bobs Creek Formation is Late Silurian to late Middle Devonian, whereas the age of the Nangahrah Formation is only poorly constrained. 


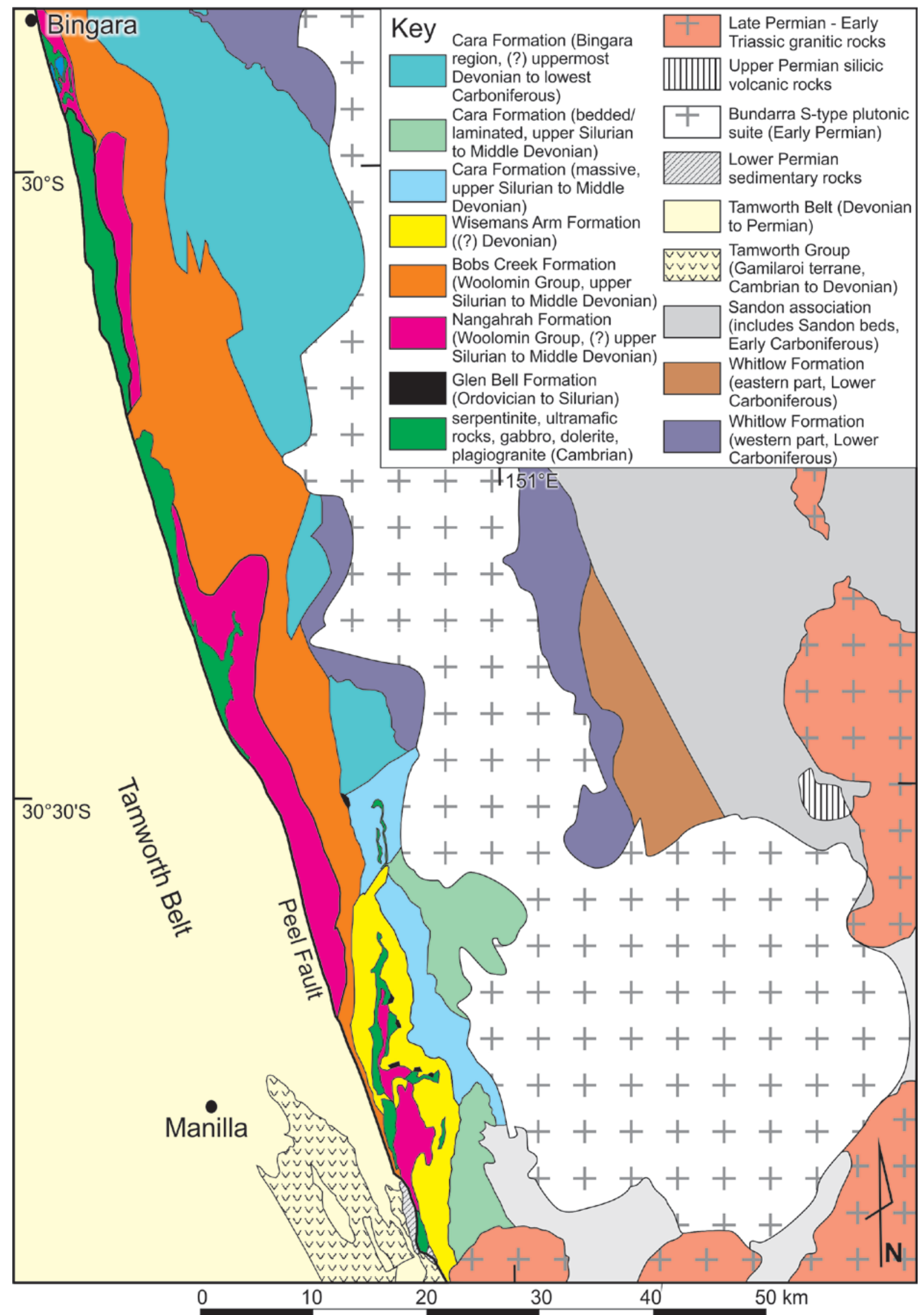

Fig. S1. Units north of Tamworth to the east of the Peel Fault in the Woolomin Group and Sandon association (after Brown et al., 2008; Vickery et al., 2010; and the seamless geological map of New South Wales, Colquhoun et al., 2015). Cenozoic sediments and 
volcanic rocks are omitted. The distribution of units in this region has been refined using closely spaced geophysical data (Brown, 2001, 2003, 2009). See Fig. 5 for location.

The Wisemans Arm Formation is a unit of massive lithic sandstone, mudstone and conglomerate with rare chert olistoliths and limestone clasts (Brown, 2009; Vickery et al., 2010). The age of the unit is poorly constrained and considered Carboniferous (Brown, 2009; Vickery et al., 2010). This is unlikely as the unit has a provenance dominated by maficintermediate igneous detritus and correlated with Lower to Middle Devonian units of the Tamworth Group (Cawood, 1983). Bedding in the unit is generally steeply west-dipping (Leitch and Cawood, 1980). It is thought to have formed in a lower trench-slope to trench setting with input of sediment mainly from the magmatic arc, but chert clasts must have been derived from the Woolomin Group (Leitch and Cawood, 1980; Brown, 2009).

East of the Woolomin Group and Wisemans Arm Formation is the Cara Formation (Fig. S1) (Vickery et al., 2010). The Cara Formation consists of two main facies that have been mapped over large areas of the Manilla 1:100,000 geological sheet: (1) massive mudstone, minor pebbly mudstone, chert and metabasalt, and (2) ribbon-bedded cherty mudstone, massive mudstone and minor metabasalt/metadolerite, and rare chert (Brown et al., 2008; Vickery et al., 2010). Radiolarians from east of Bingara indicate a Fammenian-Tournaisian (latest Devonian to earliest Carboniferous) age (Aitchison, 1988, 1990; Aitchison et al., 1992), whereas ages northeast of Manilla from conodonts in ribbon-bedded cherty mudstones indicate late Silurian to Middle Devonian (Percival in Vickery et al., 2010). The unit is typically steeply dipping (Colquhoun et al., 2015) and considered much faulted (Aitchison et al., 1988).

East of the Cara Formation in the southern Tablelands Complex is a large region of more typical subduction complex rocks with lithic sandstone, mudstone, tuffaceous mudstone, minor conglomerate, bedded chert and metabasalt. Numerous units are identified but split into two main associations by Korsch (1977), the Sandon and Coffs Harbour associations (Fig. 5). East of the Peel Fault north of Tamworth, the Sandon association from west to east includes the Whitlow Formation and Sandon beds (Figs. 5, S1) (Aitchison et al., 1988, 1992; Vickery et al., 2010). Ribbon chert occurs near the base of fault-bounded ocean plate stratigraphy with overlying lithic sandstones and mudstones formed by turbidite deposition in a trench wedge; where established the bedded cherts have Tournaisian radiolarian ages, whereas tuffaceous cherts interbedded with trench-wedge turbidites are Visean consistent with a Lower Carboniferous age for these units (Aitchison et al., 1992).

The Coffs Harbour association (Korsch, 1977) west of the Nambucca Block forms two main north-trending belts that are shown on the map as bounded by planar faults (Fig. 5), except south of Armidale where the contact is shown by radiometric data as a folded contact (Brown, 2003; Li and Rosenbaum, 2014). The Coffs Harbour association here is a turbidite succession with sandstones containing abundant silicic volcanic detritus and are more quartzose than the adjacent Sandon beds sandstones (Korsch, 1977, 1984). The unit lacks chert and metabasalt in contrast to the Sandon association and its age is Upper Carboniferous determined from $\mathrm{U}-\mathrm{Pb}$ ages of detrital zircons indicating a maximum age of deposition at $309 \mathrm{Ma}$ to the northeast of Armidale (Craven and Daczko, 2017). In the belts east and south of Armidale (Fig. 5), the Coffs Harbour association rocks are multiply-deformed with major overturning preceding several phases of upright folding and merge into low-pressure amphibolite facies metamorphics at Wongwibinda and Tia associated with Early Permian Stype granites (Korsch, 1981a; Dirks et al., 1992). 
In summary, the Southern Tablelands Complex is marked by the Woolomin Group in the west with common chert that forms a distinctive marker along the western side of the subduction complex. In contrast other accretionary units are more typical of circum-Pacific subduction complexes (e.g. Isozaki et al., 2010) and dominated by turbidites and overall young eastwards reflective of accretionary growth.

Accretionary units of the northern Tablelands Complex

More details are given below for the accretionary units that outline the Coffs Harbour and Texas oroclines. The abundance of limestone units in the core of the Texas Orocline is critical for understanding its development. Accretionary units of the northern Tablelands Complex are outlined firstly for the Coffs Harbour Orocline and then secondly for the Texas Orocline (Fig. 5).

The Willowie Creek beds only occur in the northwest of the Coffs Harbour Orocline where they lie west and southwest of the Baryulgil Serpentinite (Fig. 5). They consist of a varied assemblage of tuffaceous mudstone, fine-grained intermediate to mafic igneous rocks and less abundant greywacke, mudstone, breccia, conglomerate, chert and deformed gabbroic and dioritic rock types (Fergusson, 1984a). Structurally they are complexly deformed but structures are difficult to resolve due to abundant massive lithologies and the lack of way-up criteria. They contain limestone blocks in breccia and conglomerate but their ages are not established. Radiolarians from tuffaceous mudstones indicate a Late Devonian (Frasnian) age (Aitchison and Flood, 1992).

The Gundahl Complex is a highly disrupted unit with abundant fault slices defining a strong northwest structural grain in particular shown by discontinuous thin-bedded blue-grey bedded cherts (Figs. 5, 6) (Fergusson, 1984a, b, 1985). Numerous coherent fault slices consist of base-faulted altered mafic rocks overlain by a unit of bedded chert (10-20 m thick), overlain by mudstone with numerous thin silicic ash layers, then a coarsening upward succession of mudstone and thickening beds of lithic sandstone (Fig. S2) interpreted as an oceanic succession overlain by trench-wedge turbidites (Fergusson, 1984a, b, 1985). A radiolarian chert sample from near Jackadgery (Fig. 6) is Tournaisian (Aitchison, 1988, 1990; Aitchison and Flood, 1990, 1992). One unusual feature of the Gundahl Complex is the widespread occurrence of ooliths in lithic, dominantly volcaniclastic, sandstones of the Gundahl Complex, which are found commonly across the whole $15 \mathrm{~km}$ width of the unit (Fergusson, 1984a). Structurally, the unit is steeply dipping with widespread chaotic and highly sheared lithologies (Fergusson, 1984b). South of the Gundahl Complex are the Cunglebung Creek beds (Fig. 6) of dominantly black mudstone but the age of this unit is not known (Fergusson, 1984a). 


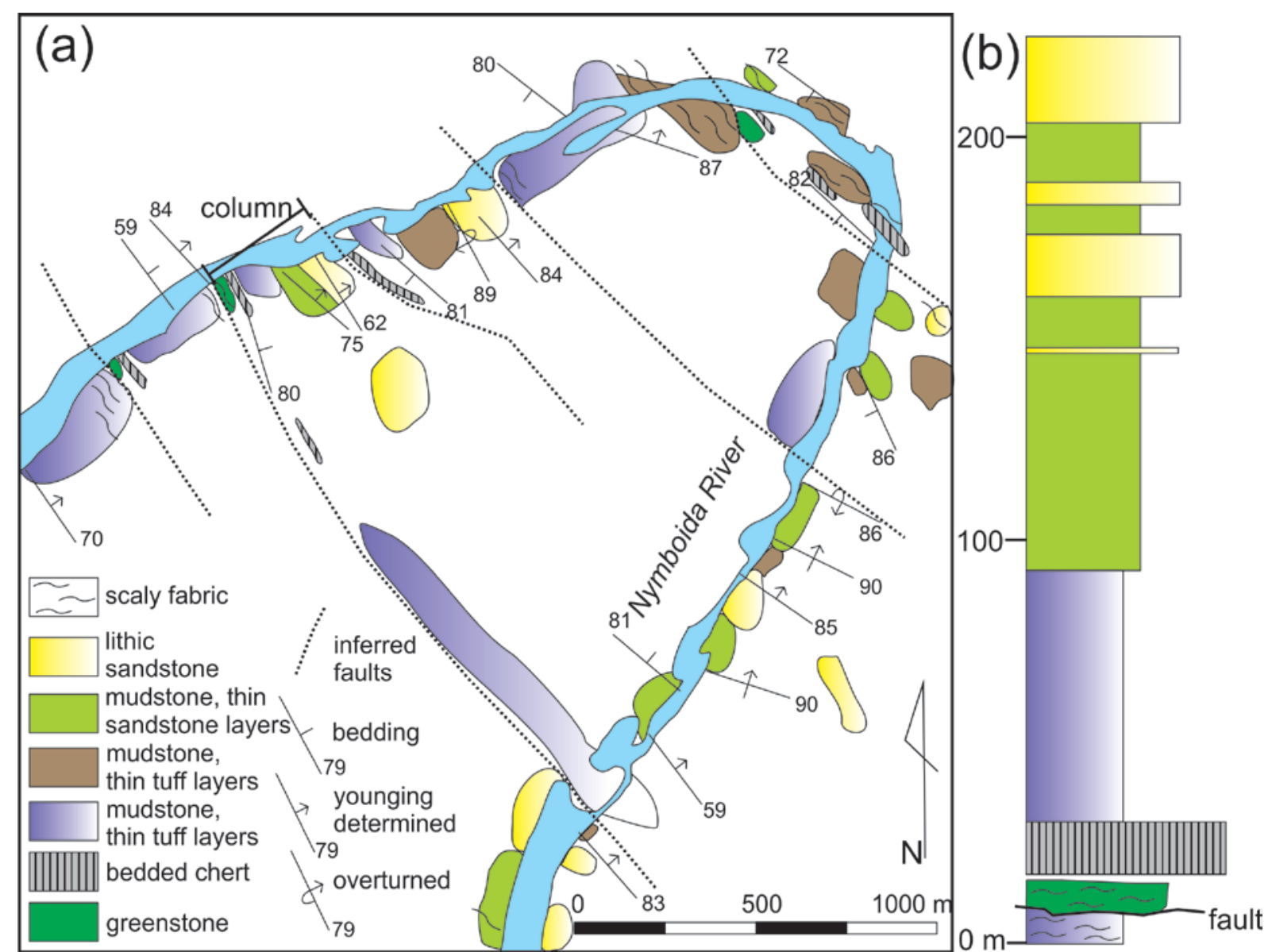

Fig. S2. Map (a) and stratigraphic column (b) of ocean plate stratigraphy and overlying truncated trench-wedge turbidites preserved in imbricate fault slices in the Gundahl Complex (modified from Fergusson, 1985). See Fig. 6 for location.

The Coffs Harbour sequence occupies most of the southern Coffs Harbour Block (Fig. 6) and is the type region of the Coffs Harbour association which is distinguished by the abundance of silicic volcanic detritus in sandstones (Korsch, 1978b, 1981b; Fergusson, 1984a). The succession is subdivided into the Coramba, Brooklana, and Moombil beds, from north to south which have decreasing sandstone content southwards with the Moombil beds mainly of black mudstone (Korsch, 1978a). Much of the succession is dominated by turbidites interpreted as trench-wedge deposits (Korsch, 1981b, 1993; Fergusson, 2010). Chert and metabasalt occur in lenses 10-150 m thick with strike lengths up to several kilometres in the Coramba and Brooklana beds (Gilligan et al., 1992, p. 15). They are affected by major deformation producing tight folds and widespread cleavage (Korsch, 1981c; Fergusson, 1982). Two sandstone samples with detrital zircon ages of $320 \mathrm{Ma}$ and $323 \mathrm{Ma}$ (Fig. 6) (Korsch et al., 2009) and a Rb/Sr isochron age of $318 \pm 8$ Ma interpreted as the timing of metamorphism (Graham and Korsch, 1985) indicate that the Coramba beds are lower Upper Carboniferous.

In the eastern limb of the Texas Orocline along the New South Wales - Queensland border (Fig. 5), the Silverwood Group of probable Silurian to Lower Devonian (Emsian) age consists of a marine succession of mafic-intermediate volcanics, tuffaceous mudstones, lithic sandstones, conglomerates, breccias, limestone lenses and limestone breccias (van Noord, 1999; Donchak et al., 2007; Donchak, 2013). Based on the geochemistry of igneous rocks and the facies assemblage the succession has an island arc - backarc tectonic setting and with 
the Willowie Creek beds has been considered an equivalent of the Lower to lower Upper Devonian Tamworth Group in the Tamworth Belt (Murray et al., 1987; Donchak et al., 2007).

Apart from outliers of Permian sedimentary and volcanic rocks, the Texas Orocline is dominated by a single unit, the Texas beds (Fig. 5), which consist of a succession of turbidites with lithic sandstones and mudstone, with minor chert, and altered mafic volcanic rocks (Donchak et al., 2007). A subunit of the Texas beds with characteristics of the Sandon association has been mapped in the northeast (Fig. 5, TbSa) (Fergusson and Flood, 1985; Donchak et al., 2007). This subunit has a distinctive magnetic and radiometric pattern compared to the remainder of the Texas beds (Donchak et al., 2007) and locally $13 \mathrm{~km} \mathrm{SSW}$ of Warwick (Fig. 5) contains oolith-bearing greywackes and other rock types typical of the Gundahl Complex, and was considered equivalent to it by Fergusson and Flood (1985). Sandstones in the Texas beds are dominated by silicic volcaniclastic detritus with minor mafic volcanic clasts, chert and rare granitic grains (Fergusson and Flood, 1985; Donchak et al., 2007; Donchak, 2013). Altered mafic volcanic rocks are widely developed, have a magmatic affinity consistent with ocean-island basalt (OIB) origin and are associated with chert, two samples of which are Visean (Aitchison and Flood, 1990a; Donchak et al., 2007). Visean limestone occurs as clasts in volcaniclastic conglomerates and forms masses up to several kilometres in length in several belts (Fig. 5) including the Ashford Limestone Member with a strike length of $14 \mathrm{~km}$ to the SSW of Texas (Flood, 1999; Donchak et al., 2007; Donchak, 2013). Limestone occurrences are associated with mafic volcanic rocks and are interpreted as accreted ocean islands overlain by coral atolls, although in some cases the limestones were dislodged during accretion and now form olistoliths in volcaniclastic turbidites (Flood, 1999; Donchak et al., 2007; Buchs et al., 2010).

In summary, the accretionary units of the Coffs Harbour and Texas oroclines include a unit of distinctive mafic volcanic and sedimentary rocks (Silverwood Group and Willowie Creek beds) that are not found in the southern Tablelands Complex but considered equivalent to Devonian island arc rocks in the Tamworth Belt to the west. Most of the accretionary units are dominated by turbidites as for most of the accretionary rocks of the southern Tablelands Complex but the Texas Orocline accretionary rocks are distinguished by the abundance of Visean limestone occurrences associated with mafic rocks of ocean island magmatic affinity.

\section{Additional References}

Aitchison, J.C., 1988. Late Paleozoic radiolarian ages from the Gwydir terrane, New England orogen, eastern Australia. Geology 16, 793-795.

Aitchison, J.C., 1990. Significance of Devonian-Carboniferous radiolarians from accretionary terranes of the New England orogen, eastern Australia. Marine Micropaleontology 15, 365-378.

Aitchison, J.C., Flood, P.G., 1990. Early Carboniferous radiolarian ages constrain the timing of sedimentation within the Anaiwan terrane, New England orogen, eastern Australia. Neues Jahrbuch für Geologie und Paläontologie - Abhandlungen180, 1-19.

Blake, M.C., Murchey, B., 1988. A California model for the New England fold belt. In: J.D. Kleeman, J.D. (Editor), New England Orogen: Tectonics and Metallogenesis. University of New England, Armidale, pp. 20-31.

Brown, R.E., Henley, H.F., Vickery, N.M., Glen, R.A., Stroud, W.J., 2008. Manilla 1:100 000 Geological Sheet 9036. Geological Survey of New South Wales, Maitland, New South Wales. 
Cawood, P.A., 1982. Structural relations in the subduction complex of the Paleozoic New England fold belt, eastern Australia. Journal of Geology 90, 381-392.

Colquhoun, G.P., Phillips, G., Hughes, K.S, Deyssing, L., Fitzherbert, J.A., Troedson, A.L., 2015. New South Wales Zone 56 Seamless Geology, version 1 [Digital Dataset]. Geological Survey of New South Wales, Maitland, New South Wales.

Craven, S.J., Daczko, N. R., 2017. The Keepit arc: provenance of sedimentary rocks in the central Tablelands Complex, southern New England Orogen, Australia, as recorded by detrital zircon. Australian Journal of Earth Sciences 64, 401-418.

Donchak, P.J.T., 2013. Northern part of southern New England Orogen extending into Queensland. In: Jell, P.A. (Ed.), The Geology of Queensland. Geological Survey of Queensland, Brisbane, Queensland, 444-466.

Fergusson, C.L., 1984b. The Gundahl Complex of the New England Fold Belt, eastern Australia: a tectonic melange formed in a Palaeozoic subduction complex. Journal of Structural Geology 6, 257-271.

Flood, P.G., 1999. Exotic seamounts within Gondwanan accretionary complexes, eastern Australia. In: Flood, P.G. (Ed.), Regional Geology. Tectonics and Metallogenesis. New England Orogen. Earth Sciences, University of New England, Armidale, New South Wales, 23-29.

Gilligan, L.B., Brownlow, J.W., Cameron, R.G., Henley, H.F., 1992. Dorrigo - Coffs Harbour 1:250,000 Metallogenic Map SH/56-10, SH/56-11: Metallogenic Study and Mineral Deposit Data Sheets, 509 pp. Geological Survey of New South Wales, Sydney, New South Wales.

Graham, I.G., Korsch, R.J., 1985. Rb-Sr geochronology of coarse-grained greywackes and argillites from the Coffs Harbour Block, eastern Australia. Chemical Geology (Isotope Geoscience Section) 58, 45-54.

Ishiga, H., Leitch, E.C., Watanabe, T., Naka, T., Iwasaki, M., 1988. Radiolarian and conodont biostratigraphy of siliceous rocks from the New England Fold Belt. Australian Journal of Earth Sciences 35, 73-80.

Korsch, R.J., 1981a. Structural geology of the Rockvale Block, northern New South Wales. Australian Journal of Earth Sciences 28, 51-70.

Korsch, R.J., 1984. Sandstone compositions from the New England Orogen, eastern Australia: implications for tectonic setting. Journal of Sedimentary Petrography 54, 192-211.

Leitch, E.C., Cawood, P.A., 1980. Olistoliths and debris flow deposits at ancient consuming plate margins: an Eastern Australian example. Sedimentary Geology 25, 5-22. 